\title{
Pathways of PFOA to the Arctic: variabilities and contributions of oceanic currents and atmospheric transport and chemistry sources
}

\author{
I. Stemmler ${ }^{1}$ and G. Lammel ${ }^{1,2}$ \\ ${ }^{1}$ Max Planck Institute for Chemistry, Mainz, Germany \\ ${ }^{2}$ Masaryk University, Research Centre for Toxic Compounds in the Environment, Brno, Czech Republic
}

Received: 14 March 2010 - Published in Atmos. Chem. Phys. Discuss.: 3 May 2010

Revised: 30 August 2010 - Accepted: 30 September 2010 - Published: 20 October 2010

\begin{abstract}
Perfluorooctanoic acid (PFOA) and other perfluorinated compounds are industrial chemicals in use for decades which resist degradation in the environment and seem to accumulate in polar regions. Transport of PFOA was modeled using a spatially resolved global multicompartment model including fully coupled three-dimensional ocean and atmosphere general circulation models, and two-dimensional top soil, vegetation surfaces, and sea ice compartments. In addition to primary emissions, the formation of PFOA in the atmosphere from degradation of 8:2 fluorotelomer alcohol was included as a PFOA source. Oceanic transport, delivered $14.8 \pm 5.0(8-23) \mathrm{t} \mathrm{a}^{-1}$ to the Arctic, strongly influenced by changes in water transport, which determined its interannual variability. This pathway constituted the dominant source of PFOA to the Arctic. Formation of PFOA in the atmosphere led to episodic transport events (timescale of days) into the Arctic with small spatial extent. Deposition in the polar region was found to be dominated by wet deposition over land, and shows maxima in boreal winter. The total atmospheric deposition of PFOA in the Arctic in the 1990s was $\approx 1 \mathrm{ta}^{-1}$, much higher than previously estimated, and is dominated by primary emissions rather than secondary formation.
\end{abstract}

\section{Introduction}

Perfluorooctanoic acid (PFOA) and its ammonium salt have been used for over 50 years as processing aids in the production. Although it is only weakly toxic, and it is low to not bioaccumulative it has aroused large scientific interest in the past years, due to its high persistency and the fact that it is distributed globally, including remote environments. Unlike the "old" persistent organic pollutants, which are mostly

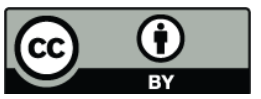

Correspondence to: G. Lammel (g.lammel@mpic.de) hydrophobic and semivolatile, PFOA is non-volatile and exists in dissociated (ionic) and non-dissociated forms (Goss and Arp, 2009). Still, it was detected in the abiotic and biotic Arctic environment (Martin et al., 2004; Stock et al., 2007; Young et al., 2007). As there are no primary sources of PFOA in the Arctic this indicates that it is transported over long distances from continental mid-latitudes (or further). Three transport pathways have been suggested: oceanic transport of the anion, atmospheric transport of primary emitted PFOA, and transport of volatile precursor substances that are converted to PFOA. Previous modeling studies (Armitage et al., 2006; Wania, 2007; Schenker et al., 2008) suggest a larger contribution from oceanic than from atmospheric transport. The spatial resolution of these studies was limited, however, and the episodic nature of atmospheric transport was not captured. The seasonality of contaminant flow in the atmosphere from mid to high northern latitudes is such that most is delivered in winter, while summer accounts for only $\approx 20 \%$ (Barrie et al., 1992; Iversen, 1996; Hung et al., 2005). The zonal distributions of both atmospheric and oceanic transports of organic pollutants in high latitudes are very inhomogeneous with most being delivered via the European sector (Barrie et al., 1992; Iversen, 1996; Macdonald et al., 2000; AMAP, 2004). Furthermore, recent studies have demonstrated the importance of interannual variability of the atmospheric dynamics (AMAP, 2004); Halsall et al., 1998) and episodic long-range transports in air (Halsall et al., 1998; Eckhardt et al., 2003, 2007; Wang et al., 2010) on the exposure of the Arctic environment towards pollutants. The aims of this study are to quantify the significance of oceanic and atmospheric transport routes to the Arctic and of primary and main secondary PFOA sources, and to explore how atmosphere and ocean dynamics variabilities are reflected in the poleward contaminant flow. To this end and in contrast to previous studies, a multicompartment chemistry-transport model based on a coupled atmosphere-ocean general circulation model (AOGCM) is used. This approach bears the

Published by Copernicus Publications on behalf of the European Geosciences Union. 
advantage of including realistically varying circulation patterns in atmosphere and ocean, thereby providing the opportunity of studying the transport behaviour in a fully dynamic and coupled system. Atmospheric intermediates of PFOA formation as well as their oxidants are explicitly and fully dynamically modeled, albeit using a simplified chemistry, and wet and dry, gaseous and particulate phase depositions are described. Thereby, the yield of PFOA from one precursor, 8:2 FTOH, is simulated. PFOA cycling in the ocean includes vertical export due to both deep water formation and particle settling.

\section{Methods}

\subsection{Model description}

The multicompartment chemistry-transport model MPIMCTM (Lammel et al., 2001; Semeena et al., 2006; Guglielmo et al., 2009) is based on the three-dimensional coupled atmosphere-ocean general circulation model ECHAM5-HAM/MPIOM-HAMOCC (Roeckner et al., 2003; Marsland et al., 2003; Stier et al., 2005; Maier-Reimer et al., 2005), with embedded two-dimensional top soil and vegetation surfaces. In HAM (Stier et al., 2005), aerosols are represented by seven log-normal modes, four soluble and three insoluble. The mass of the chemical components and number concentrations are predicted by the model. HAM takes into account the aerosol components sulphate, black carbon, organic carbon (primary and secondary), mineral dust and seasalt. The Hamburg Ocean Carbon Cycle Model HAMOCC5 uses a nutrient-phytoplankton-zooplanktondetritus (NPZD-type) ecosystem model (Maier-Reimer et al., 2005; Six and Maier-Reimer, 1996) and a carbon chemistry formulation (Maier-Reimer, 1993). Chemicals cycle in atmosphere (gaseous, aqueous and particulate phases), ocean (dissolved, colloidal, and particulate phases), and soil and vegetation surfaces. Cycling in the model includes degradation, transport, and exchange processes, which have been described previously (Semeena et al., 2006; Guglielmo et al., 2009). In atmospheric aerosols, partitioning is empirically based on the octanol-air partitioning coefficient, $\mathrm{K}_{\mathrm{oa}}$, and doubling of the particulate mass fraction is assumed per $4.9 \mathrm{~K}$ temperature decrease (Semeena et al., 2006). In the 3-D ocean, in addition to advection (3-D, i.e. including deep water formation and upwelling) and diffusion, chemicals in the particulate phase are subject to gravitational settling at the same velocity as detritus $\left(5 \mathrm{~m} \mathrm{~d}^{-1}\right)$. Partitioning to the particulate phase is calculated from the organic carbon partitioning coefficient, $\mathrm{K}_{\mathrm{oc}}$ (Guglielmo et al., 2009).

\subsubsection{Emissions}

Perfluorooctanoic acid primary emission rates for 19502004 are based on estimates of PFO (perfluorooctanoate) emission from fluoropolymer production (Armitage et al.,
2006; Prevedouros et al., 2006). Point sources from fluoropolymer manufacture account for more than $60 \%$ of total emissions of perfluorocarboxylates (Prevedouros et al., 2006). Other sources, such as aqueous fire fighting foams or consumer products are neglected. We use a highly simplified emission scenario, which concentrates historic major and minor sources of various temporal profiles into globally 4 point sources, which are constant over time. These are meant to represent the main producers, i.e. in the USA, Japan, Belgium, and Italy. In fact, the sources in these countries and also neglected sources in minor manufacturing countries (e.g. China) have been historically located in the mid northern latitudes, i.e. $\approx 30-50^{\circ} \mathrm{N}$. Although this simplified emission source distribution excludes the ability to study distributions and gradients in the sources' latitudes, the aims of the study, large-scale poleward transports and gradients, are not affected. The compartmental split upon entry of primary PFOA emissions is assumed to be $23 \%$ into the atmosphere, $65 \%$ into the ocean, and $12 \%$ into top soils (Prevedouros et al., 2006). For Italy, Belgium and Japan the emissions to the ocean are assumed to end up in the adjacent Adriatic Sea, North Sea and Pacific Ocean (Tokyo Bay), respectively. The emission source for the US is located in the Midwest and in the St. Lawrence water shed. As the Great Lakes are not represented in the model in terms of a water compartment for chemical cycling, it is assumed that PFOA is transferred in the Gt. Lakes and St. Lawrence River system and added to seawater at the mouth of the St. Lawrence River. Boulanger et al. (2005), show that volatilization of PFOA in Lake Ontario is less than $1 \%$ of the inflow. Therefore we adopt a $1 \%$ loss rate, neglecting any other loss than volatilization. The same loss rate as for the St. Lawrence River is used for Lake Erie, Lake Michigan and Lake Huron. As soon as the substance enters the model atmosphere or ocean, partitioning in the multiphase system takes place. The temporal distribution follows Prevedouros et al. (2006), and is shown in Fig. 1.

8:2 fluorotelomer alcohol (FTOH) is released to the environment during both the manufacture and use of fluorotelomer-based products. To capture both entry pathways, the model simulated emission rates based on telomer A production (Prevedouros et al., 2006) with the spatial distribution determined by the gross domestic product at market exchange rate of 1990 (GDP data from the IIASA GGI Scenario Database, 2007). The FTOH emission rates equal $2 \%$ of the estimated telomer A production. Global and temporal distribution of FTOH emissions are show in Fig. 2. Other PFOA precursors than 8:2 FTOH, such as longerchain FTOH congeners, fluorooctanesulfamido alcohols, fluorotelomer olefin, acrylate and iodide congeners (Prevedouros et al., 2006; Martin et al., 2006), are neglected. 

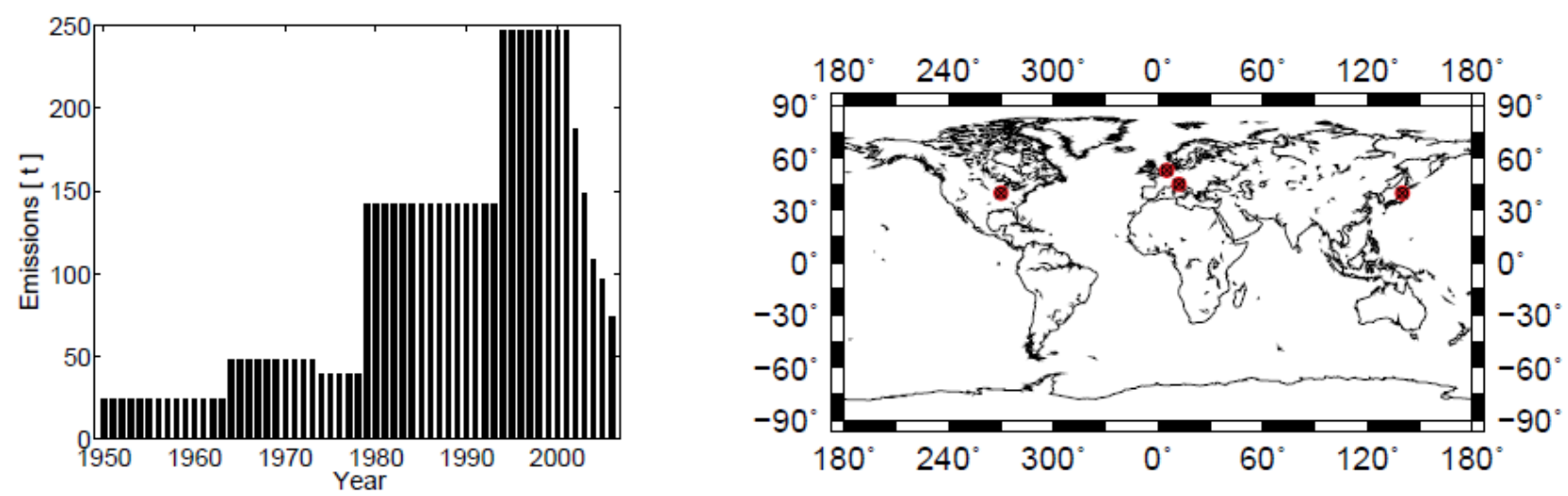

Fig. 1. PFOA emissions: temporal $\left[\mathrm{ta}^{-1}\right]$ and spatial distributions.
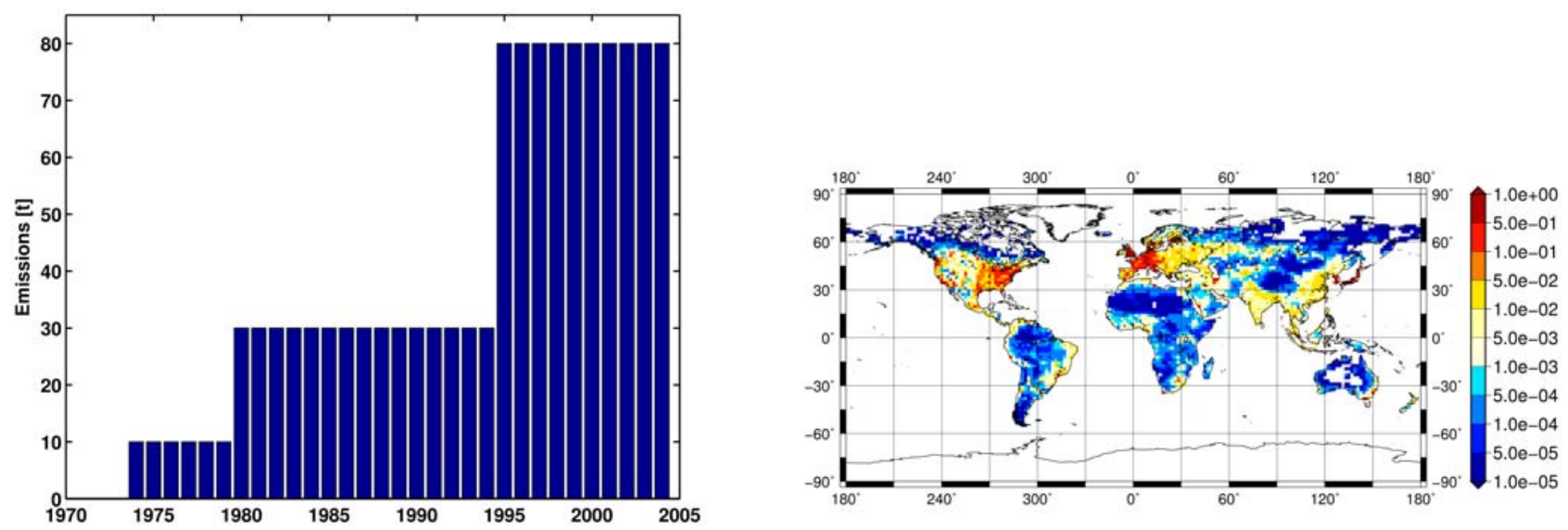

Fig. 2. FTOH emissions: temporal $\left[\mathrm{ta}^{-1}\right]$ and spatial $\left[\mathrm{ta}^{-1}, 1^{\circ} \times 1^{\circ}\right]$ distributions.

\subsection{Atmospheric PFOA precursor chemistry}

Formation of PFOA in the atmosphere by degradation of FTOH is based on a simplified oxidation mechanism (Wallington et al., 2006). Only those substances are considered in the model, which have an expected lifetime in the atmosphere long enough to be transported and/or alter PFOA yield, i.e. the aldehydes $\mathrm{C}_{8} \mathrm{~F}_{17} \mathrm{CH}_{2} \mathrm{CHO}$ and $\mathrm{C}_{8} \mathrm{~F}_{17} \mathrm{CHO}$, the peroxy radicals $\mathrm{C}_{8} \mathrm{~F}_{17} \mathrm{C}(\mathrm{O}) \mathrm{O}_{2}$ and $\mathrm{C}_{8} \mathrm{~F}_{17} \mathrm{O}_{2}$, and the alcohol $\mathrm{C}_{8} \mathrm{~F}_{17} \mathrm{OH}$. Five inorganic reactants, i.e. $\mathrm{OH}, \mathrm{NO}$, $\mathrm{NO}_{2}, \mathrm{HO}_{2}$, and $\mathrm{CH}_{3} \mathrm{O}_{2}$, are included in the atmospheric chemistry module. The oxidation mechanism is briefly explained here: The first stable product of the telomer alcohol, $\mathrm{C}_{8} \mathrm{~F}_{17} \mathrm{CH}_{2} \mathrm{CH}_{2} \mathrm{OH}$, in atmospheric chemistry is the aldehyde $\mathrm{C}_{8} \mathrm{~F}_{17} \mathrm{CH}_{2} \mathrm{CHO}$. It is formed with $100 \%$ yield via the Reaction (R1), which includes the reaction of FTOH with $\mathrm{OH}$, followed by the resulting hydroxyalkyl radical reaction with $\mathrm{O}_{2} \cdot \mathrm{C}_{8} \mathrm{~F}_{17} \mathrm{CH}_{2} \mathrm{CHO}$ reacts in Reaction (R2) with $\mathrm{OH}$ and forms upon addition of $\mathrm{O}_{2}$ a peroxyacyl radical, $\mathrm{C}_{8} \mathrm{~F}_{17} \mathrm{CH}_{2} \mathrm{C}(\mathrm{O}) \mathrm{OO}$. This radical is partly stored as a thermolabile peroxyacyl nitrate, $\mathrm{C}_{8} \mathrm{~F}_{17} \mathrm{CH}_{2} \mathrm{C}(\mathrm{O}) \mathrm{OONO}_{2}$, upon addition of $\mathrm{NO}_{2}$ (Reaction $\mathrm{R} 3 \mathrm{c}$ ) and may react with either $\mathrm{NO}$ to the peroxy radical $\mathrm{C}_{8} \mathrm{~F}_{17} \mathrm{CH}_{2} \mathrm{COO}$ (Reaction $\mathrm{R} 3 \mathrm{~b}$ ), or with $\mathrm{HO}_{2}$ to the carboxylic acid, $\mathrm{C}_{8} \mathrm{~F}_{17} \mathrm{CH}_{2} \mathrm{COOH}$ (Reaction $\mathrm{R} 3 \mathrm{a}$ ). $\mathrm{C}_{8} \mathrm{~F}_{17} \mathrm{CH}_{2} \mathrm{COO}$ loses one $\mathrm{O}$ to $\mathrm{NO}$ and stabilizes upon $\mathrm{H}$-abstraction by $\mathrm{O}_{2}$ as perfluorononanal, $\mathrm{C}_{8} \mathrm{~F}_{17} \mathrm{CHO}$ (Reaction $3 \mathrm{~b}$ ). The branching yield between these two products, $\mathrm{C}_{10}$-acid and $\mathrm{C}_{9}$-aldehyde, is assumed to be $60 \%: 40 \%$. The acid's chemical fate was neglected as irrelevant for PFOA formation. The aldehyde, $\mathrm{C}_{8} \mathrm{~F}_{17} \mathrm{CHO}$, is again activated by $\mathrm{OH}$ attack and yields $\mathrm{C}_{8} \mathrm{~F}_{17} \mathrm{C}(\mathrm{O}) \mathrm{OO}$ in Reaction (R4), which, also, loses an O by reaction with $\mathrm{NO}(100 \%$ yield) forming the peroxy radical $\mathrm{C}_{8} \mathrm{~F}_{17} \mathrm{OO}$ (Reaction R5a) or with $\mathrm{HO}_{2}(90 \%)$ (Reaction R5b), while it is assumed that $10 \%$ of it in the latter reaction will obtain an $\mathrm{H}$ and lose $\mathrm{O}_{3}$ by formation of perfluorononanoic acid, $\mathrm{C}_{8} \mathrm{~F}_{17} \mathrm{COOH}$ (PFNA). This species, as irrelevant for PFOA formation, was also neglected. For the photodissociation of the aldehyde, $\mathrm{C}_{8} \mathrm{~F}_{17} \mathrm{CHO}$, a low effective quantum yield, similar to the one of $\mathrm{CF}_{3} \mathrm{CHO}, \leq 0.02$ (Sellevåg et al., 2004), was adopted by (Wallington et al., 2006). Because of the lack of experimental data, the photodissociation of $\mathrm{C}_{8} \mathrm{~F}_{17} \mathrm{CHO}$ was also 
neglected, in contrast to the approach used by Wallington et al., 2006. The peroxy radical $\mathrm{C}_{8} \mathrm{~F}_{17} \mathrm{OO}$ reacts with several radicals, $\mathrm{NO}$ (Reaction R6a), $\mathrm{NO}_{2}$ (Reaction R6b), and $\mathrm{CH}_{3} \mathrm{O}_{2}$ (Reaction R6b). Only the Reaction (R6c) with the methylperoxy radical is considered in the model as it forms the alcohol $\mathrm{C}_{8} \mathrm{~F}_{17} \mathrm{OH}$ via elimination of HF. The alcohol is converted into the acid fluoride $\mathrm{C}_{7} \mathrm{~F}_{15} \mathrm{C}(\mathrm{O}) \mathrm{F}$, which in turn, upon rapid hydrolysis forms $\mathrm{PFOA}, \mathrm{C}_{7} \mathrm{~F}_{15} \mathrm{COOH}$, combined as Reaction (R7).

$\mathrm{FT} 1=\mathrm{C}_{8} \mathrm{~F}_{17} \mathrm{CH}_{2} \mathrm{CH}_{2} \mathrm{OH}$,

$\mathrm{FT} 2=\mathrm{C}_{8} \mathrm{~F}_{17} \mathrm{CH}_{2} \mathrm{CHO}$,

$\mathrm{FT} 3=\mathrm{C}_{8} \mathrm{~F}_{17} \mathrm{CHO}$,

$\mathrm{FT} 4=\mathrm{C}_{8} \mathrm{~F}_{17} \mathrm{C}(\mathrm{O}) \mathrm{O}_{2}$,

FT5 $=\mathrm{C}_{8} \mathrm{~F}_{17} \mathrm{O}_{2}$,

FT6 $=\mathrm{C}_{8} \mathrm{~F}_{17} \mathrm{OH}$,

$\mathrm{PFOA}=\mathrm{C}_{7} \mathrm{~F}_{15} \mathrm{COOH}$

$\mathrm{FT} 1+\mathrm{OH} \rightarrow \mathrm{FT} 2$

$\mathrm{FT} 2+\mathrm{OH} \rightarrow \mathrm{C}_{8} \mathrm{~F}_{17} \mathrm{CH}_{2} \mathrm{C}(\mathrm{O}) \mathrm{OO}$

$\mathrm{C}_{8} \mathrm{~F}_{17} \mathrm{CH}_{2} \mathrm{C}(\mathrm{O}) \mathrm{OO}+\mathrm{HO}_{2} \rightarrow \mathrm{C}_{8} \mathrm{~F}_{17} \mathrm{COOH}$

$\mathrm{C}_{8} \mathrm{~F}_{17} \mathrm{CH}_{2} \mathrm{C}(\mathrm{O}) \mathrm{OO}+\mathrm{NO} \rightarrow \mathrm{FT} 3$

$\mathrm{C}_{8} \mathrm{~F}_{17} \mathrm{CH}_{2} \mathrm{C}(\mathrm{O}) \mathrm{OO}+\mathrm{NO}_{2} \rightarrow \mathrm{C}_{8} \mathrm{~F}_{17} \mathrm{CH}_{2} \mathrm{C}(\mathrm{O}) \mathrm{OONO}_{2}$
$\mathrm{C}_{8} \mathrm{~F}_{17} \mathrm{CH}_{2} \mathrm{C}(\mathrm{O}) \mathrm{OONO}_{2} \rightarrow \mathrm{C}_{8} \mathrm{~F}_{17} \mathrm{CH}_{2} \mathrm{C}(\mathrm{O}) \mathrm{OO}+\mathrm{NO}_{2}(\mathrm{R} 3 \mathrm{c})$

$\mathrm{FT} 3+\mathrm{OH} \rightarrow \mathrm{FT} 4$

$\mathrm{FT} 4+\mathrm{NO} \rightarrow \mathrm{FT} 5$

$\mathrm{FT} 4+\mathrm{HO}_{2} \rightarrow \mathrm{FT} 5$

$\mathrm{FT} 5+\mathrm{NO} \rightarrow$ unspecified products

$\mathrm{FT} 5+\mathrm{NO} 2 \rightarrow$ unspecified products

$\mathrm{FT} 5+\mathrm{CH}_{3} \mathrm{OO} \rightarrow$ FT6

FT6 $\rightarrow$ PFOA

Precursor species are transported in the gaseous phase only. Their dry deposition velocities (Wesely, 1989) and uptake into cloudwater and below-cloud scavenging are calculated according to their Henry's law constants (listed as Table 1). Global distributions of the inorganic reactants were obtained from a multi-year run of a chemistry-transport model (MOZART-4), forced by present-day climate (Emmons et al., 2009). The radical concentrations were adopted accounting for seasonal variations (monthly means), apart from diurnal cycles. Primary emission to the atmosphere is the only source of FTOH.

\subsection{Physico-chemical properties}

Physico-chemical properties relevant for the multmedia fate of PFOA and the precursor substances are listed in Table 1. Dissociation of PFOA is not treated explicitly in the model, but considered in the parameterisation of air-sea exchange. The Henry's law coefficient was derived from the dimensionless air-water partitioning coefficient, $\mathrm{K}_{\mathrm{aw}}$, and its temperature dependence as adopted from a physico-chemical data base and is uncertain by approximately a factor of 2 (Arp and Goss, 2009). The effective Henry's law coefficient, $K^{H^{*}}$, a function of the $p K_{a}\left(K^{H^{*}}(T)=K^{H}(T) \times\left(1+K_{a} / c_{H^{+}}\right)\right.$with $K_{a}=$ PFOA dissociation constant and $c_{H^{+}}=$acidity of the aqueous phase), was used to account for the non-dissociated acid as the volatile species in seawater for the calculation of the volatilisation rate. $\mathrm{pK}_{\mathrm{a}}=2.8$ was adopted (Table 1 ). However, considerably lower values, $-0.5-0.0$, are currently discussed (Goss , 2008; Burns et al., 2008; Arp and Goss, 2009). PFOA fugacity from seawater and, hence, the volatilisation rate from the sea surface would be dampened by its stronger acidity were a such low, currently discussed $p K_{a}$ value adopted. However, volatilization from the sea surface is a negligible source of PFOA in air. Therefore, PFOA concentration in air is hardly influenced by volatilisation from the sea surface: Given the lower estimate of the volatilisation rate, the global volatilisation flux from sea to air would be $0.0015 \mathrm{kga}^{-1}$, corresponding to $5 \times 10^{-6}$ of the total PFOA flux from surfaces, instead of $3 \mathrm{~kg} \mathrm{a}^{-1}$ or 0.01 flux from surfaces.

As cloudwater $\mathrm{pH}$ is not calculated in the model, the Henry's law coefficient was not adjusted to PFOA dissociation equilibrium as a function of cloudwater $\mathrm{pH}$ (effective Henry's law coefficient). Otherwise, the properties of the dissociated compound, perfluorooctanoate, are used in the model. The effect of uncertainties of physico-chemical properties on PFOA multicompartmental fate and transport is a tendency to overestimate the atmospheric burden and lifetime and, hence, atmospheric transport.

\subsection{Experiments}

The model is run un-forced by observations, i.e. generates its own realistic climate (including interannual climate variability). In one experiment atmospheric and oceanic transports of primary emitted PFOA were studied over 14 years (19912004, AOT experiment) and in a second experiment atmospheric transports of PFOA and its precursors were studied over 4 years (1995-1998, ATC experiment). In the ATC experiment the model was not coupled to the OGCM allowing for the exclusive study of atmospheric transport. Here, the ocean was represented only by climatological mean cycles of sea surface temperature and mixed layer depth (Semeena and Lammel, 2003; Semeena et al., 2006). Processes included are deposition, volatilisation and removal from the surface ocean. As PFOA deposition to the oceans in reality 
Table 1. Physico-chemical properties of $\mathrm{PFOA}$ and precursor substances. Data given for $298 \mathrm{~K}$ unless otherwise stated. $\quad \mathrm{FTOH}=\mathrm{C}_{8} \mathrm{~F}_{17} \mathrm{CH}_{2} \mathrm{CH}_{2} \mathrm{OH}$, intermediates: $\mathrm{FT} 2=\mathrm{C}_{8} \mathrm{~F}_{17} \mathrm{CH}_{2} \mathrm{CHO}$, FT3 $=\mathrm{C}_{8} \mathrm{~F}_{17} \mathrm{CHO}, \mathrm{FT} 4=\mathrm{C}_{8} \mathrm{~F}_{17} \mathrm{C}(\mathrm{O}) \mathrm{O}_{2}, \quad \mathrm{FT} 5=\mathrm{C}_{8} \mathrm{~F}_{17} \mathrm{O}_{2}$, FT6 $=\mathrm{C}_{8} \mathrm{~F}_{17} \mathrm{OH}$.

\begin{tabular}{|c|c|c|c|c|c|c|c|}
\hline Property & PFOA & FTOH & FT2 & FT3 & FT4 & FT5 & FT6 \\
\hline Saturation vapor pressure $\mathrm{p}_{\mathrm{sat}}[\mathrm{Pa}]$ & $4.2^{\mathrm{a}}$ & & & & & & \\
\hline Enthalpy of vaporisation $\mathrm{H}_{\mathrm{vap}}\left[\mathrm{kJ} \mathrm{mol}^{-1}\right]$ & $95^{\mathrm{b}}$ & & & & & & \\
\hline Water solubility $\mathrm{s}\left[\mathrm{g} \mathrm{L}^{-1}\right]$ & $14.2^{\mathrm{c}}$ & & & & & & \\
\hline Henry constant $\left[\mathrm{molL}^{-1} \mathrm{at}^{-1}\right]$ & $40^{\mathrm{d}}$ & $0.002^{\mathrm{d}}$ & $0.0259^{\mathrm{e}}$ & $0^{\mathrm{d}}$ & $0^{\mathrm{f}}$ & $0^{\mathrm{f}}$ & $40^{\mathrm{b}}$ \\
\hline Enthalpy of solution $\mathrm{H}_{\mathrm{sol}}\left[\mathrm{kJ} \mathrm{mol}^{-1}\right]$ & $2.5^{\mathrm{g}}$ & & & & & & \\
\hline Octanol-air partitioning coefficient $\log \mathrm{K}_{\mathrm{oa}}$ & $6.8^{\mathrm{h}}$ & & & & & & \\
\hline Soil organic carbon partitioning coefficient & 2.06 & & & & & & \\
\hline $\log \mathrm{K}_{\mathrm{oc}}\left[\mathrm{Lg}^{-1}\right]$ & $4.06^{\mathrm{i}}$ & & & & & & \\
\hline Dissociation constant $\mathrm{pK}_{\mathrm{a}}$ & $2.8^{\mathrm{j}}$ & & & & & & \\
\hline $\begin{array}{l}\text { OH gas-phase reaction rate coefficient } \\
\mathrm{k}_{\mathrm{OH}}\left[10^{-12} \mathrm{~cm}^{3} \mathrm{molec}^{-1} \mathrm{~s}^{-1}\right]^{\mathrm{k}}\end{array}$ & $0.169^{1}$ & $32^{\mathrm{e}}$ & $100^{\mathrm{e}}$ & $17^{\mathrm{e}}$ & & & \\
\hline $\begin{array}{l}\text { Gas-phase reaction rate coefficients with } \\
\text { other reactant } i, k_{i} \text {, else than } \\
\text { OH }\left[10^{-12} \mathrm{~cm}^{3} \text { molec }^{-1} \mathrm{~s}^{-1}\right]^{\mathrm{k}}\end{array}$ & & & & & $\begin{array}{r}0.43^{\mathrm{m}} \\
8.1^{\mathrm{n}}\end{array}$ & $\begin{array}{l}0.1^{\mathrm{o}} \\
2.8^{\mathrm{n}}\end{array}$ & \\
\hline $\begin{array}{l}\text { First-order degradation rate in compartment } \mathrm{j} \\
\mathrm{k}_{\mathrm{deg}}\left[\mathrm{s}^{-1}\right]\end{array}$ & $0^{\mathrm{p}}$ & & & & & & $2.3 \times 10^{-6 \mathrm{q}}$ \\
\hline
\end{tabular}

\footnotetext{
${ }^{a}$ Kaiser et al., 2005; 0.008 at $293 \mathrm{~K}$ for the dissociated form; ${ }^{\mathrm{b}}$ Smit et al., 1997; estimate 146 for the dissociated form; ${ }^{\mathrm{c}} 295 \mathrm{~K}$ (Prevedouros et al., 2006 ); ${ }^{\mathrm{d}}$ derived from $\mathrm{K}_{\mathrm{aw}}$; ${ }^{\mathrm{e}}$ Wallington et al. (2006); ${ }^{\mathrm{f}}$ as very short-lived; ${ }^{\mathrm{g}}$ Tomasič et al. (1995); ${ }^{\mathrm{h}}$ Arp et al. (2006); ${ }^{\mathrm{i}}$ Higgins and Luthy (2006), and estimate (see text); ${ }^{\mathrm{j}}$ Brace (1962); ${ }^{\mathrm{k}}$ represented as functions of temperature; ${ }^{1}$ Hurley et al. $(2004) ;{ }^{\mathrm{m}} \mathrm{i}=\mathrm{HO}_{2}$ (Wallington et al., 2006); ${ }^{\mathrm{n}} \mathrm{i}=\mathrm{NO}$ (Wallington et al., 2006); ${ }^{\mathrm{o}} \mathrm{i}=\mathrm{CH}_{3} \mathrm{OO}\left(\mathrm{Wallington}\right.$ et al., 2006); ${ }^{\mathrm{p}} \mathrm{j}=\mathrm{seawater}$ ocean sediment, top soil and on vegetation surfaces; ${ }^{\mathrm{q}} \mathrm{j}=$ air.
}

encompass primary emitted and secondarily formed PFOA, while the latter is neglected in this decoupled modeling approach, the oceanic transports (AOT experiment) are underestimated (not fully covered). This discrepancy is small, however, as it will be shown below. The atmospheric transport is fully covered (sum of AOT and ATC experiments), because there is no feedback (i.e. re-volatilisation) expected from the neglected depositions back to the atmosphere: PFOA is in its dissociated form not subject to volatilization from seawater. Emissions were identical in time and space in the two experiments. Initial concentrations of PFOA for the AOT experiment were obtained from a long-term simulation (1950-1990) using the 3-D AOGCM in the horizontal resolution T21/GR30, i.e. about $5^{\circ}$ and 19 levels in the atmosphere, and $3^{\circ}$ and 40 levels in the ocean. The resolution of the atmosphere model was T63L19 with a time step of $20 \mathrm{~min}$, and in the AOT experiment the ocean used a nominal resolution of $1.5^{\circ}$, where the grid cell size varies gradually between $15 \mathrm{~km}$ in the Arctic and approximately $184 \mathrm{~km}$ in the tropics. The ocean model resolves 40 vertical levels with level thickness increasing with depth. The time step of the ocean model was $72 \mathrm{~min}$ and the coupling time step was 1 day. Since PFOA tends to form multiple layers, the octanol-water partitioning coefficient, $\mathrm{K}_{\mathrm{ow}}$, cannot be measured for PFOA (US EPA, 2005). Partitioning to organic matter can also be expressed using the partitioning coefficient to organic carbon. Arp et al. (2006) found that common methods like the adsorption and $\mathrm{K}_{\mathrm{oa}}$ absorption models to predict the gas-particle partitioning underestimate the amount of perfluorinated compounds bound to organic matter. The actual, effective sorption to an organic phase dispersed in water will exceed the sorption to the same phase not dispersed in water, because of the substances' amphiphilic nature (Tolls and Sijm, 2000). The exceedance will be a function of the surface-to-volume ratio of the interface. In order to estimate the impact of partitioning to organic matter two different sorption coefficients, a lower 
and an upper estimate to quantify effective sorption deviating by a factor of 100, are adopted in lack of better knowledge: $\mathrm{K}_{\mathrm{oc}}=115 \mathrm{~mL} \mathrm{~g}^{-1}\left(\log \mathrm{K}_{\mathrm{oc}}=2.06\right)$ as measured by Higgins and Luthy (2006), was chosen as the lower estimate and a $\log \mathrm{K}_{\mathrm{oc}}=4.06$ was chosen as the upper estimate. This choice is in very good agreement with recent experimental evidence (Sakurai et al., 2010).

\subsection{Model evaluation: comparison of predicted and observed FTOH and PFOA levels}

Due to lack of monitoring data for the simulated period model evaluation is based on comparisons on a point-to-point basis using mostly data from individual campaigns. Note, that this allows us to evaluate spatial gradients and, eventually, temporal trends qualitatively only and predicted burdens on an order-of-magnitude basis.

\subsubsection{FTOH in air}

The mean level of FTOH in the near-ground $\operatorname{Arctic}\left(>70^{\circ} \mathrm{N}\right)$ atmosphere is predicted (ATC experiment) to be $0.05 \mathrm{pg} \mathrm{m}^{-3}$ under emission levels of the years 1995-1998. The maximum daily mean is $0.3 \mathrm{pg} \mathrm{m}^{-3}$ and locally up to $3.4 \mathrm{pg} \mathrm{m}^{-3}$ is predicted in spring. The predicted seasonality well captures the Arctic haze season and suggests a pronounced episodic nature of FTOH abundances, even when averaging over the entire Arctic (Fig. 3). The predicted values compare with $\approx 4(<1-20) \mathrm{pg} \mathrm{m}^{-3}$ and $\approx 15(5-22) \mathrm{pg} \mathrm{m}^{-3}$ FTOH, reported from an island, $73^{\circ} \mathrm{N}$, and a cruise in the Canadian Archipelago in the summers of 2004 (Stock et al., 2007) and 2005 (Shoeib et al., 2006), respectively. Earlier modeling studies suggested $3-5 \mathrm{pg} \mathrm{m}^{-3}$ for 1998 using the same historic emission estimates (Schenker et al., 2008) and typically $35-350 \mathrm{pg} \mathrm{m}^{-3}$ using a factor of 12.5 higher emission estimates (for "remote ocean and Arctic locations"; Wallington et al., 2006). In recent years, FTOH should have increased. Other modeling studies suggested 2-30 $\mathrm{pg} \mathrm{m}^{-3}$ (Wania, 2007) and $10-20 \mathrm{pg} \mathrm{m}^{-3}$ (Schenker et al., 2008) as mean concentrations for the near-ground Arctic atmosphere during the years 2001-2005. In mid latitudes our model predicts higher levels, such as $1.5(0.01-$ 16.4) $\mathrm{pg} \mathrm{m}^{-3}$ (monthly mean (daily min-daily max)) at the Irish West coast, $0.9(0.1-2.3) \mathrm{pg} \mathrm{m}^{-3}$ in Oregon $\left(44^{\circ} \mathrm{N}\right)$ and $0.3(0.003-1.4) \mathrm{pg} \mathrm{m}^{-3}$ in the subtropic Pacific Ocean $\left(\right.$ Okinawa, $\left.27^{\circ} \mathrm{N}\right)$. These ranges overlap, hence compare reasonably with measured data ranges, i.e. $11.3 \mathrm{pg} \mathrm{m}^{-3}$ for West Ireland (Piekarz et al., 2007), and $<1-18 \mathrm{pg} \mathrm{m}^{-3}$ and $<1-3 \mathrm{pg} \mathrm{m}^{-3}$ for Oregon and Okinawa, respectively (Barber et al., 2007). Because of the coarse emission scenario, the predicted distributions within the sources' latitudes, i.e. $\approx 30-50^{\circ} \mathrm{N}$, are expected to deviate significantly from reality.

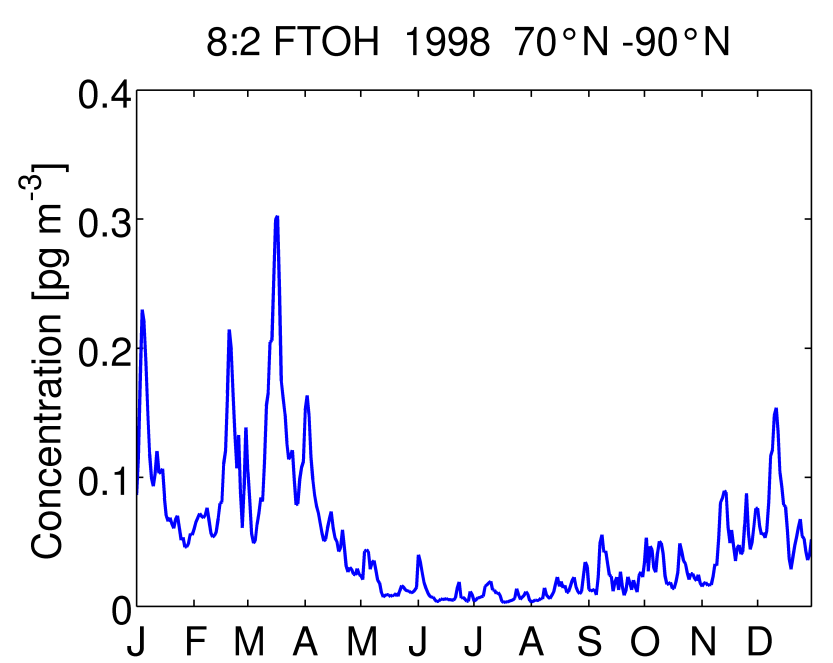

Fig. 3. One-year time series of daily mean concentration of $8: 2$ FTOH in the near-ground Arctic atmosphere (1998, spatially averaged over $>70^{\circ} \mathrm{N}$ ).

\subsubsection{PFOA in air and atmospheric deposition}

The model predicted for the ATC experiment mean PFOA levels in the Arctic $\left(60-90^{\circ} \mathrm{N}\right)$ in January and July are $3.9-4.9 \mathrm{pg} \mathrm{m}^{-3}$. While $2.8-3.4 \mathrm{pg} \mathrm{m}^{-3}$ prevail in the $\mathrm{Eu}-$ ropean Arctic $\left(60-80^{\circ} \mathrm{N}, 10^{\circ} \mathrm{W}-60^{\circ} \mathrm{E}\right)$, the model predicts $2.5-4.5 \mathrm{pg} \mathrm{m}^{-3}$ for the Central Arctic $\left(80-90^{\circ} \mathrm{N}\right)$ and 4.2$5.1 \mathrm{pg} \mathrm{m}^{-3}$ for the Canadian Archipelago $\left(60-80^{\circ} \mathrm{N}, 60-\right.$ $\left.130^{\circ} \mathrm{W}\right)$. These compare reasonably well with observed levels in the range $0-4 \mathrm{pg} \mathrm{m}^{-3}$ in summer 2004 in the Canadian Archipelago ( $73^{\circ} \mathrm{N}, 93^{\circ} \mathrm{W}$; Stock et al., 2007). In May, in mid latitudes $1.5(0.04-10.1) \mathrm{pg} \mathrm{m}^{-3}$ are predicted for the North Atlantic (monthly mean (daily min-daily max), at the West coast of Ireland $\left(53^{\circ} \mathrm{N}\right)$ and $0.6(0.08-1.2) \mathrm{pg} \mathrm{m}^{-3}$ in Northern Norway $\left(70^{\circ} \mathrm{N}\right)$ assuming $\log \mathrm{K}_{\mathrm{oc}}=4.06$ for the year 2004. These compare with observations of 8.9 and $4.4 \mathrm{pg} \mathrm{m}^{-3}$, respectively, in the year 2005 (Piekarz et al., 2007; same month). Later observations cannot be compared as our experiment did not cover the subsequent years, when emissions were cut back significantly (Prevedouros et al., 2006). PFOA atmospheric deposition in the Arctic, 1.06$1.19 \mathrm{ta}^{-1}\left(\log \mathrm{K}_{\mathrm{oc}}=2.06\right)$ and $0.92-1.04 \mathrm{ta}^{-1}\left(\log \mathrm{K}_{\mathrm{oc}}=4.06\right)$, is almost entirely attributed to primary PFOA, while only $35-46 \mathrm{~kg}$ (for both substance scenarios) are formed from $8: 2 \mathrm{FTOH}$. This latter amount corresponds to $\approx 0.05 \%$ of the global FTOH emissions $\left(80 \mathrm{ta}^{-1}\right)$. Considering different spatial emission distributions in the various studies (Wallington et al., 2006; Wania, 2007; Schenker et al., 2008), this fraction compares well with $\approx 0.04 \%$ ( $40 \mathrm{t}$ out of $1000 \mathrm{t}$ of annual FTOH emission), which had been estimated using a 3-D global atmospheric chemistry model (Wallington et al., $2006)$, with $\approx 0.1-0.2 \%$ (0.06-0.15 t out of 30-200 t; Wania, 2007 ) and $\approx 0.1 \%$ ( $0.1 \mathrm{t}$ out of $80 \mathrm{t}$; Schenker et al., 2008), 
which were both based on simulations using zonally averaged multimedia fate and transport models. Using a regional atmospheric chemistry model (Yarwood et al., 2007) it was predicted that $0.25-2.5 \%$ of the FTOH emissions in North American would be deposited as PFOA in the Arctic. Here it is found that among atmospheric deposition of PFOA in the Arctic, primary sources dominate with $\approx 95 \%$ (see below). A similar prediction had been made using a zonally averaged model (Wania, 2007). Furthermore, it is in agreement with an atmospheric chemistry model study (Wallington et al., 2006): In this study PFOA levels in the Arctic in the range $0.07-1.4 \mathrm{pg} \mathrm{m}^{-3}$ (in January and July) had been predicted and these levels were due to secondary PFOA only, i.e. formed from $1000 \mathrm{t}$ of annual FTOH emissions (12.5 higher than used in our study) which had been distributed globally according to the distribution of industrial propane. Also Armitage et al., 2009, found $0.46-2.53 \mathrm{ta}^{-1}$ gross deposition flux to the Arctic in 2005 when simulating $\mathrm{PFO}(\mathrm{A})$ $\left(\mathrm{pK}_{\mathrm{a}}=3.5\right)$ transport from direct sources with a global spatially resolved multimedia fate model.

\subsubsection{PFOA in seawater}

PFOA in seawater was measured in the Atlantic, Indian and Pacific Oceans between 2002 and 2006 in the context of a global ocean monitoring initiative (Yamashita et al., 2008). Vertical profiles were sampled in the Labrador Sea, the Mid Atlantic Ocean, the South Pacific Ocean and the Sea of Japan, where water probes were done to several depths down to $5500 \mathrm{~m}$. The limit of quantification for PFOA was $6 \mathrm{pg} \mathrm{L}^{-1}$. Vertical profiles from different ocean regions differ significantly from each other. In the Labrador Sea (Fig. 4) PFOA concentrations are $50 \mathrm{pg} \mathrm{L}^{-1}$ at the surface for both model results (AOT experiment) and observations. For AO1 (Atlantic Ocean at $56^{\circ} 34^{\prime} \mathrm{N} 52^{\circ} 48^{\prime} \mathrm{W}$ ) and AO2 (Atlantic Ocean at $56^{\circ} 41^{\prime} \mathrm{N} 39^{\circ} 40^{\prime} \mathrm{W}$ ) modeled profiles are almost identical, while observed profiles behave differently. Concentrations in water samples at AO1 are relatively constant throughout depth, except for subsurface water, where the PFOA concentration decreases, and water below $2000 \mathrm{~m}$, in which concentrations again increase. Modeled concentrations, as well as observed ones at $\mathrm{AO} 2$, decrease until $500 \mathrm{~m}$, and remain constant down to $2000 \mathrm{~m}$. In waters below $2000 \mathrm{~m}$ PFOA concentration increases for observations, but decreases in the model results. Yamashita, 2008 suggest that water masses from the surface down to $2000 \mathrm{~m}$ were well mixed due to their convective formation. The subsurface is explained by Yamashita, 2008 by a decrease caused by the influx of the melt-water rich Labrador current, and the increase in larger depths by the presence of an independent deep water current carrying higher amounts of PFOA. A similar stratification is observed in the model results, except for the deep water current, that decreases concentrations in waters below $2000 \mathrm{~m}$. In the mid Atlantic Ocean observed concentrations at $\mathrm{AO} 3\left(23^{\circ} 17^{\prime} \mathrm{N} 64^{\circ} 19^{\prime} \mathrm{W}\right)$ and $\mathrm{AO} 4\left(25^{\circ} 47^{\prime} \mathrm{N}\right.$ $\left.64^{\circ} 59^{\prime} \mathrm{W}\right)$ decrease gradually with depth, whereas at AO5 $\left(27^{\circ} 03^{\prime} \mathrm{N} 64^{\circ} 35^{\prime} \mathrm{W}\right)$ they show an increase until $500 \mathrm{~m}$ and a decrease below. Modeled profiles show a similar pattern. Surface concentrations of model results, however, are much lower than the observed ones. The reason could be unrealistic emissions with regard to temporal profile (assumed in phase everywhere) and global source strength (not all source types are captured; see Sect. 2.1.1). Furthermore, the prediction of similar profiles for all mid Atlantic sampling locations results from the missing riverine source into the mid Atlantic Ocean in the emissions scenario: emissions from North American fluoropolymer production sites, which in reality are located both in the St. Lawrence and the Mississipi basins, are released into the Atlantic Ocean solely at the mouth of the St. Lawrence River, while discharge of PFOA into the Gulf of Mexico is not considered (see Sect. 2.1.1). Profiles in the Sea of Japan are similar for model and observational data. The concentration decreases down to $1000 \mathrm{~m}$ and remains constant below. The concentrations in the surface layer are lower for the modeled profiles, most likely in consequence of the emission scenario, which concentrates the sources in the region in to one point source (in Japan), assumes identical temporal profiles for all source points and does not capture all emitted mass. Due to the limited horizontal resolution of models, the topography of the ocean differs from the real one. In the Southern Ocean concentrations were low throughout all depths, and for the measurements often below the detection limit of $6 \mathrm{pg} \mathrm{L}^{-1}$. The gradient of PFOA concentrations in surface seawater in the Altantic Ocean along the West Coast of the European and African continents predicted for the latest year of the AOT experiment compares well with measured concentrations from ship in October/November 2005 (Theobald et al., 2007). Modeled concentrations decrease from $500-600 \mathrm{pg} \mathrm{L}^{-1}$ in the North Sea, 50-60 pg L ${ }^{-1}$ in the Bay of Biscay and Atlantic Ocean west of Maroc and the Western Sahara, down to 7-10 $\mathrm{pg} \mathrm{L}^{-1}$ in the Gulf of Guinea. Theobald et al. found decreasing concentrations of $50-90 \mathrm{pg} \mathrm{L}^{-1}$ in the Bay of Biscay to less than $17 \mathrm{pg} \mathrm{L}^{-1}$ (limit of quantification) south of the equator in the Gulf of Guinea.

\section{Results and discussion}

\subsection{Degradation of FTOH to PFOA}

The precursors' distributions in the global atmosphere (FT3, FT4, FT6, see Fig. 5) reflect the four point sources in the northern mid latitudes. Their abundances are limited by the radicals' availabilities (low latitudes, summer hemisphere), i.e. maximum burden is predicted to be coincident with the radicals' distributions (Fig. 5). Unlike its precursors, zonal mean PFOA maxima are found evenly distributed over mid to high northern latitudes with the exception of summer months, when concentrations are lower, in particular in high 
a.
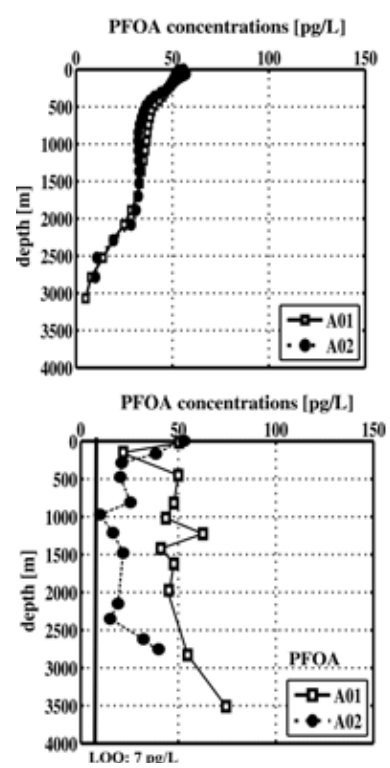

b.
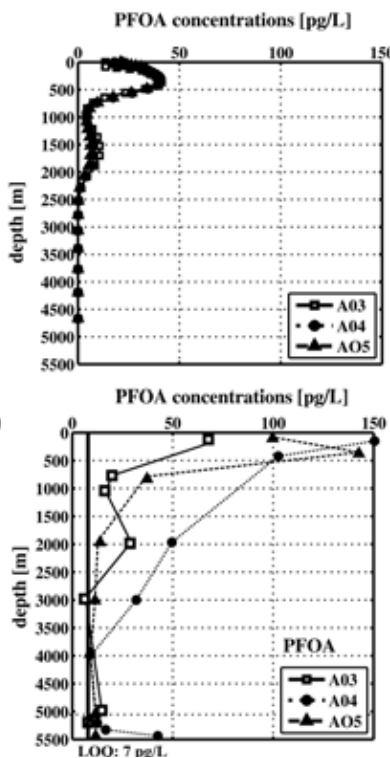

c.

PFOA concentrations $[\mathrm{pg} / \mathrm{L}]$

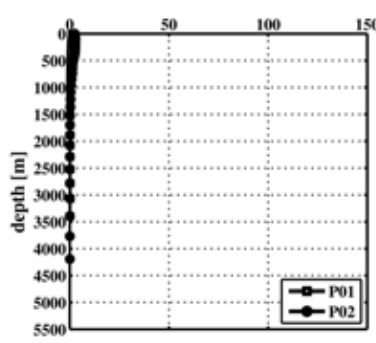

PFOA concentrations $[\mathrm{pg} / \mathrm{L}]$

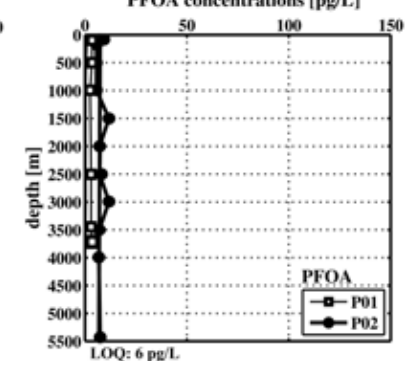

d.
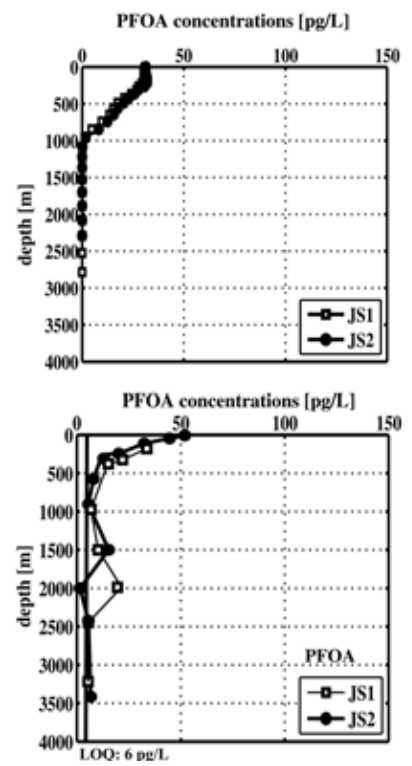

Fig. 4. Vertical profiles of PFOA concentration $\left[\mathrm{pg} \mathrm{L}^{-1}\right]$ in the Labrador Sea (AO1, AO2), Mid Atlantic Ocean (AO3, AO4, AO5), Sea of Japan (JS1, JS2), and the South Pacific Ocean (PO1,PO2); upper panels model results, lower panels observations (Yamashita et al., 2008). (a) September 2004, AO1: $56^{\circ} 34^{\prime} \mathrm{N} 52^{\circ} 48^{\prime} \mathrm{W}$, AO2: $56^{\circ} 41^{\prime} \mathrm{N} 39^{\circ} 40^{\prime} \mathrm{W}$ (b) March 2004, AO3: $23^{\circ} 17^{\prime} \mathrm{N} 64^{\circ} 19^{\prime} \mathrm{W}, \mathrm{AO}^{\circ}: 25^{\circ} 47^{\prime} \mathrm{N}$ 64 $59^{\prime} \mathrm{W}$, AO5: $27^{\circ} 03^{\prime} \mathrm{N} 64^{\circ} 35^{\prime} \mathrm{W}$ (c) December 2004, PO1: $67^{\circ} 12^{\prime} \mathrm{S} 169^{\circ} 57^{\prime} \mathrm{W}$ PO2: $39^{\circ} 59^{\prime} \mathrm{S} 169^{\circ} 59^{\prime} \mathrm{W}$ (d) May 2005 , JS1: $40^{\circ} 43^{\prime} \mathrm{N} 136^{\circ} 24^{\prime} \mathrm{E}, \mathrm{JS} 2: 44^{\circ} 12^{\prime} \mathrm{N} 138^{\circ} 54^{\prime} \mathrm{E}$.

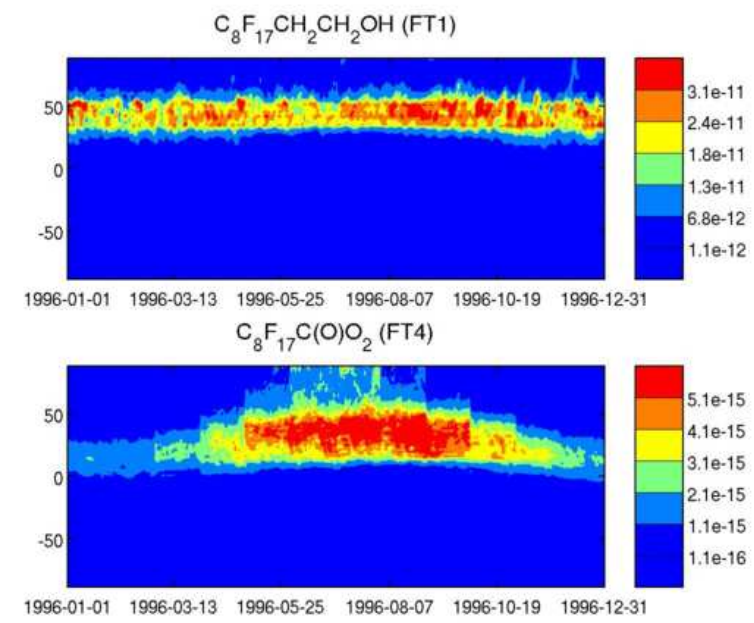

PFOA

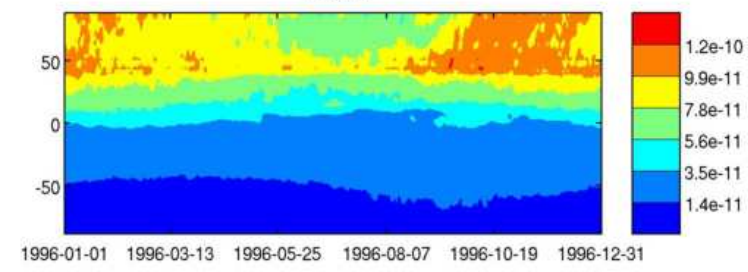

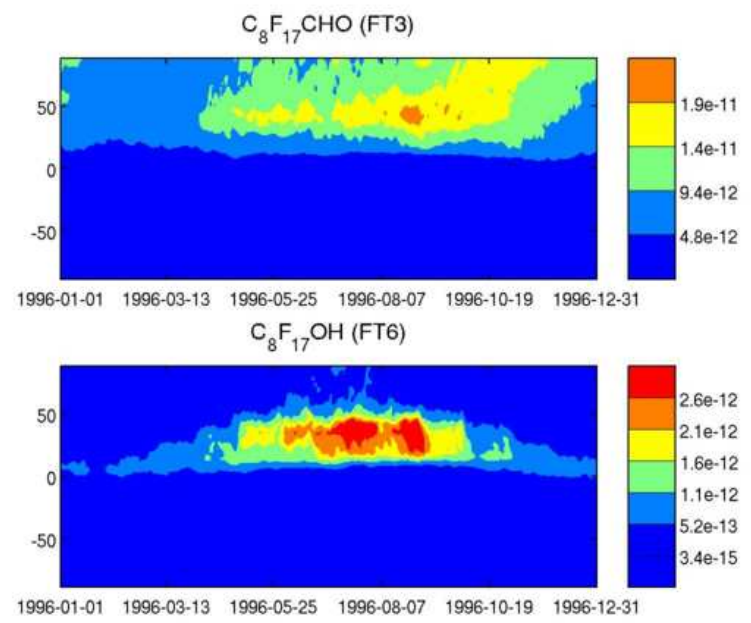

$\begin{array}{lllllll}1996-01-01 & 1996-03-13 & 1996-05-25 & 1996-08-07 & 1996-10-19 & 1996-12-31\end{array}$

Fig. 5. One-year time series of the latitudinal distribution of daily 8:2 fluorotelomer alcohol (FT1), $\mathrm{C}_{8} \mathrm{~F}_{17} \mathrm{CHO}(\mathrm{FT} 3), \mathrm{C}_{8} \mathrm{~F}_{17} \mathrm{C}(\mathrm{O}) \mathrm{O}_{2}(\mathrm{FT} 4)$, $\mathrm{C}_{8} \mathrm{~F}_{17} \mathrm{OH}$ (FT6), and PFOA atmospheric burdens $\left[\mathrm{kg} \mathrm{m}^{-2}\right]$. 

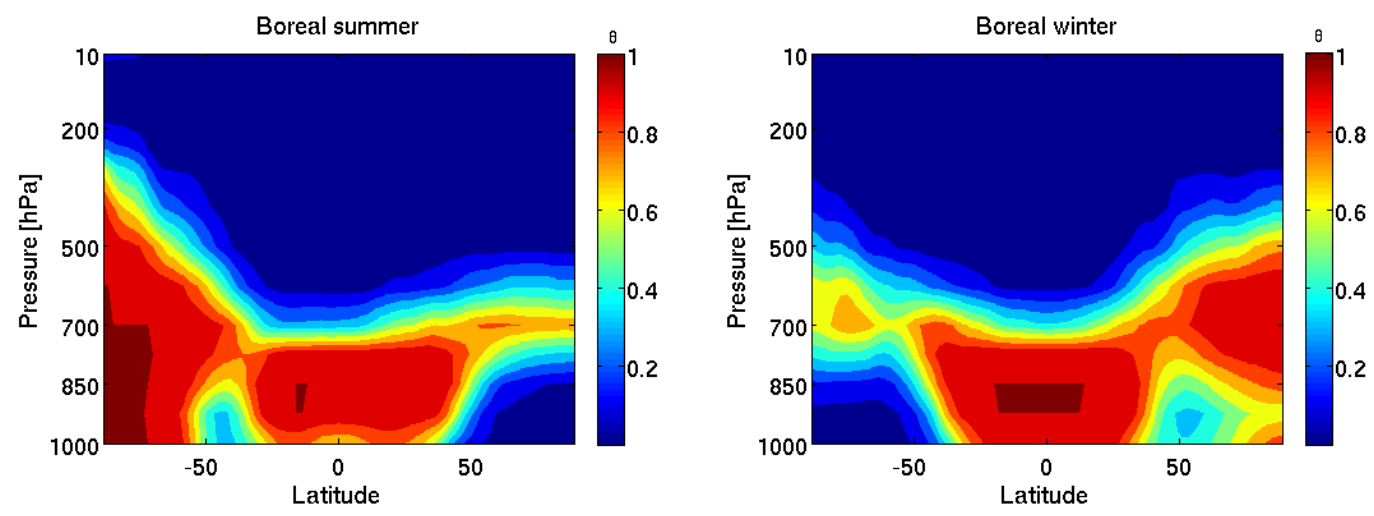

Fig. 6. Model-predicted vertical distributions of seasonal and zonal mean particle-associated fraction, $\theta$, of PFOA (log $\mathrm{K}_{\mathrm{oc}}=2.06$, simulated year 1998).

latitudes (Fig. 5). The reason for this is transport, which is not effective for the precursors because of their short lifetime: the characteristic atmospheric lifetime of the immediate precursor, $\mathrm{C}_{8} \mathrm{~F}_{17} \mathrm{OH}$, with regard to conversion to PFOA is about 5 days independent of temperature, i.e. 2 orders of magnitude longer than the characteristic lifetimes of the other intermediates of FTOH chemistry, radicals and aldehydes, which are formed within $<4 \mathrm{~h}$ in the full relevant temperature range, 233-298 K. Poleward transport events are limited in spatial scale and occur during episodes of a few days, predominantly in the cold season (provided as animation in the Supplementary Material, see Supplement), as investigated in other studies (Macdonald et al., 2000; Wang et al., 2010). Averaging makes these appear to be more extended in time and space. Main transport routes are determined by the lower tropospheric high pressure systems, and include northward transport from Eastern Europe and Siberia, transport poleward across the North Atlantic Ocean, and transport across the Bering Sea (see Supplement, animation). The mean level of FTOH in the near-ground Arctic $\left(>70^{\circ} \mathrm{N}\right)$ atmosphere is predicted to be $0.05 \mathrm{pg} \mathrm{m}^{-3}$ under emission levels of the years $1995-1998$. The maximum daily mean is $0.3 \mathrm{pg} \mathrm{m}^{-3}$ and locally up to $3.4 \mathrm{pg} \mathrm{m}^{-3}$ are predicted in spring (see Sect. 2.6 for a comparison with other studies). The predicted seasonality well captures the Arctic haze season and suggests a pronounced episodic nature of FTOH abundances, even when averaging over the entire Arctic (Fig. 6). Between August and October a secondary maximum of PFOA concentration can be observed in the Southern Hemisphere (SH). The centre of this maximum is temporally located over Eastern Africa or stretches eastward and southward off the African coast over the Indian Ocean (towards Madagascar). It corresponds to a maximum of the immediate precursor, $\mathrm{C}_{8} \mathrm{~F}_{17} \mathrm{OH}$, which, in turn, is related to a FTOH area source in the region (Kenya).

\subsection{Atmospheric concentration and deposition of PFOA}

Model predicted mean PFOA levels in the Arctic (60$90^{\circ} \mathrm{N}$ ) in January and July are $3.9-4.9 \mathrm{pg} \mathrm{m}^{-3}$. While $2.8-3.4 \mathrm{pg} \mathrm{m}^{-3}$ prevail in the European Arctic $\left(60-80^{\circ} \mathrm{N}\right.$, $\left.10^{\circ} \mathrm{W}-60^{\circ} \mathrm{E}\right)$, the model predicts $2.5-4.5 \mathrm{pg} \mathrm{m}^{-3}$ for the Central Arctic $\left(80-90^{\circ} \mathrm{N}\right)$ and $4.2-5.1 \mathrm{pg} \mathrm{m}^{-3}$ for the Canadian Archipelago $\left(60-80^{\circ} \mathrm{N}, 60-130^{\circ} \mathrm{W}\right)$. Thereby, PFOA concentrations in the Central Arctic are higher in January than in July, due to transport events occurring predominantly in winter.

There are considerable uncertainties in the chemical mechanism adopted. For example, some rate coefficients and branching ratios had been estimated because of the lack of kinetic data and are currently debated (e.g. Sulbaek Andersen et al., 2006). The phase state (gas-particle partitioning) predicted by the model may deviate from the ambient air partitioning. The model predicts PFOA particulate mass fractions, $\theta$, varying widely: $\theta>0.7$ is predicted in the atmospheric boundary layer and free troposphere in the tropics and subtropics throughout the year and in high latitudes in winter. $\theta<0.3$ is predicted in high latitudes in summer and in the upper troposphere throughout the year (Fig. 6). Observations in the near-ground polluted atmosphere reported predominant transport of PFOA in the particulate phase (Barton et al., 2007, but also equal partitioning between gas and particulate phases Kim and Kannan, 2007; similar type of site, same season). If atmospheric transport was predominantly in the particulate phase and secondary sources were negligible for deposition in the Arctic, then the seasonality of PFOA levels in Arctic air and the latitudinal gradient should be similar to those of other organic pollutants originating mostly in the mid latitudes for which $\theta=1$, e.g. 56 ring polycyclic aromatic hydrocarbons (PAH). PAH levels in the Canadian Archipelago in winter exceed those in summer by 1-2 orders of magnitude (Macdonald et al., 2000; Wang et al., 2010). No PFOA observations in Arctic winter 

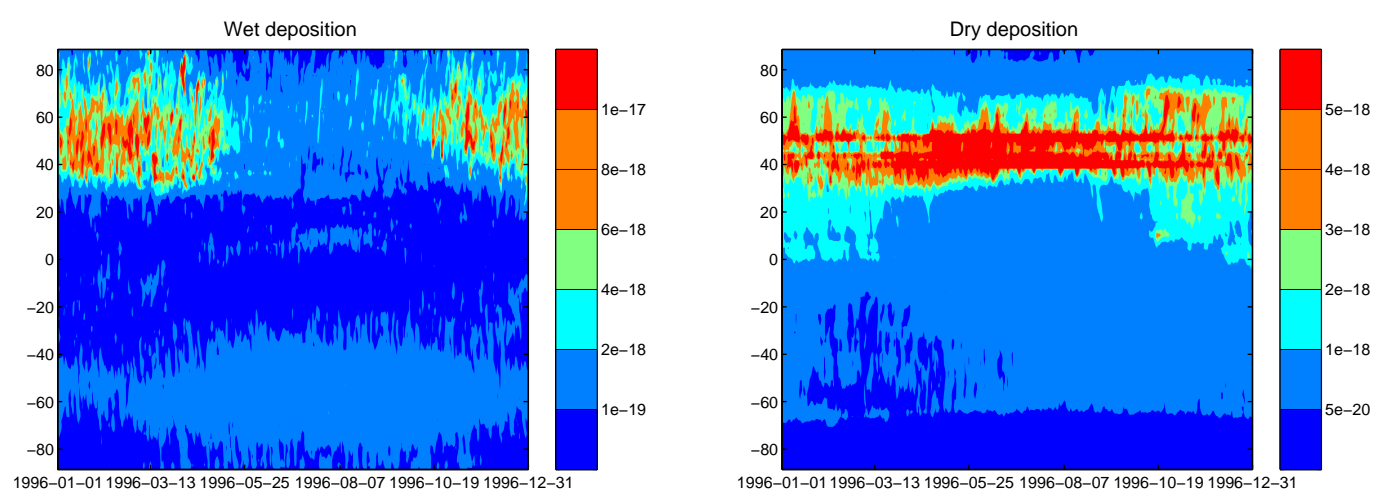

Fig. 7. One-year time series of the latitudinal distribution of daily mean PFOA wet and dry deposition $\left[\mathrm{kg} \mathrm{m}^{-2} \mathrm{~s}^{-1}\right]$.

air have been reported. 1-2 orders of magnitude higher than the summer levels, however, is highly unlikely given the midlatitude observations, which are in the same order of magnitude (Stock et al., 2007; Piekarz et al., 2007). In conclusion, this reasoning supports the perception that $\theta$ of PFOA will deviate significantly from 1 , at least under some of the relevant environmental conditions along poleward long-range transport (aerosol abundance, temperature). A recent modelling study (Armitage et al., 2009) suggested little influence of the PFOA phase state on poleward long-range transport. Deposition of PFOA is highest in the mid latitudes of the Northern Hemisphere, between $30^{\circ} \mathrm{N}$ and $70^{\circ} \mathrm{N}$. While wet deposition shows a strong seasonal variation with high values in the boreal winter and spring and low values in summer, dry deposition is almost constant throughout the year. It is highest close to the four primary emission sources, where $23 \%$ were directly emitted to the atmosphere. These appear in the time series of the zonal means as continuous lines at the latitudes of the sources (Fig. 7).

The seasonal variation of wet deposition is defined by the seasonal variation of PFOA atmospheric mixing ratio, and the precipitation flux. The latter was shown to be well covered by the ECHAM5 model, albeit slightly overestimating in boreal summer over the ocean (Hagemann et al., 2006; Roesch and Roeckner, 2006). A secondary maximum of the wet deposition occurs in the mid latitudes of the $\mathrm{SH}$, due to the location of the SH jet stream and associated low pressure systems. PFOA in that area partly originates from interhemispheric transport over the Inter-Tropical Convergence Zone, but also from formation of PFOA in the SH due to FTOH sources in South America, Australia, and Southern Africa. Deposition of PFOA in the Arctic is probably underestimated as the AGCM fails to simulate the effectiveness of poleward transports during the Arctic haze "season" (Shindell et al., 2008). It was derived by integrating total deposition spatially over the area north of $70^{\circ} \mathrm{N}$ (Fig. 8). Note that wet deposition is almost exclusively limited to the Eurasian and North American continent, and the Northern Atlantic Ocean,

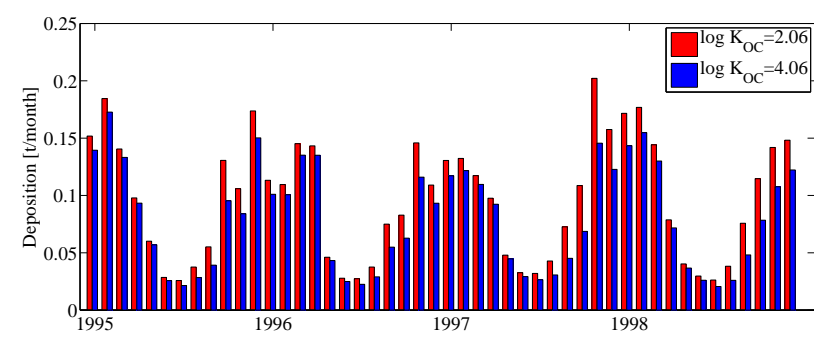

Fig. 8. Four-year time series of monthly sums of total (wet + dry) deposition $[t]$ of PFOA to the Arctic.

whereas the central Arctic Ocean receives almost no wet deposition. This is due to the governing meteorological conditions of the central Arctic, characterized by strong inversions. The spatially integrated deposition follows a repeated strong annual cycle, with maxima in winter.

This deposition maximum in winter is in contrast to a field study (Young et al., 2007) and two model studies (Wania, 2007; Wallington et al., 2006) that report PFOA deposition maxima in spring and summer. The maximum corresponds to the high atmospheric burden in winter, and indicates that not transport of the precursors into the Arctic and subsequent oxidation and deposition of PFOA, but emissions from primary sources to the atmosphere and formation of PFOA in low and mid latitudes and episodic transport into the Arctic determines the atmospheric PFOA route. In the Canadian Arctic the model predicts the same seasonality as found by Young et al., 2007 (minimum in winter, maximum in springsummer), but for only some of the simulated years, while no clear long-term seasonality of total depostion is predicted during the simulated years. Whether the model captures the correct seasonality could only be judged on basis of a longer simulation. Annually $1.06-1.19 \mathrm{t}\left(\log \mathrm{K}_{\mathrm{oc}}=2.06\right)$ or $0.92-$ $1.04 \mathrm{t}\left(\log \mathrm{K}_{\mathrm{oc}}=4.06\right)$ of PFOA are deposited to the Arctic. This range is by far higher than the total deposition to the 
Arctic of $0.27 \mathrm{t} \mathrm{a}^{-1}$ estimated by Young et al. (2007) based on PFOA deposition measured to four ice caps across the Canadian Arctic in 2005. However, this flux has to be interpreted with caution due to the high spatial variability of deposition. Corresponding to lower concentrations the more lipophilic tracer shows less deposition in the Arctic. The PFOA deposition in the Arctic is almost entirely attributed to primary PFOA, while only $35-46 \mathrm{~kg}$ (for both substance scenarios) are formed from 8:2 FTOH. This latter amount corresponds to $\approx 0.05 \%$ of the global FTOH emissions $\left(80 \mathrm{ta}^{-1}\right)$.

\subsection{Oceanic transport to the Arctic}

The model predicts (AOT experiment) $14.8 \pm 5.0 \mathrm{ta}^{-1}$, annually between $8 \mathrm{t}$ (1994) and $23 \mathrm{t}$ (1998), transported to the Arctic ocean with oceanic currents (Fig. 9). The finding of much more mass being transferred into the Arctic by the ocean transports than by atmospheric transports confirms previous findings (Armitage et al., 2006; Wania, 2007; Schenker et al., 2008) of oceanic transport being the dominant transport pathway to the Arctic. The oceanic import corresponded to $2 \%$ (1994) or to $14 \%$ (2004) of the global emission flux. In contrast to previous estimates (Armitage et al., 2006; Wania, 2007) the import to the Arctic Ocean is not increasing steadily over time, but is fluctuating in a non-regular manner. This is the result of the combined effect of interannual climate variability, emissions and chemodynamics of substance stored and cycling in the multicompartmental system. The emission rate of PFOA (Fig. 1), increasing from 1990 to 2004, is dominating, but is overcompensated for by the variability of oceanic currents. The Arctic Ocean is surrounded by continents and connected with adjacent oceans via the Barents Sea, the Bering Strait, the Davis Strait, and the Fram Strait. The vertically integrated transports over the 4 (each shortest) lines which cross the Norwegian Sea, Denmark Strait, Davis Strait, and Bering Strait are budgeted in Fig. 9. It is found that the main source of PFOA to the Arctic Ocean is inflow through the Norwegian Sea. Annually between 10 and $30 \mathrm{t}$ are imported via the Norwegian coastal current, which accounts for $50-80 \%$ of the total transport across these lines. This pronounced inhomogeneity across longitudes is in agreement with studies of other pollutants, i.e. organochlorine pesticides and polycyclic aromatic hydrocarbons (Macdonald et al., 2000; AMAP, 2004; Halsall et al., 1998). Transport out of the Arctic occurs mainly in the Denmark strait, where some of the northward flowing water is returned to the Atlantic Ocean in a subsurface flow along the Greenland east coast (Aakrog et al., 1987). This outflow of PFOA amounts to $4-10 \mathrm{ta}^{-1}$. Only 0.6 to $1.5 \mathrm{ta}^{-1}$ of PFOA originating from the point source in Japan are reaching the Arctic Ocean through the Bering Strait. The Pacific Ocean current system is dominated by a large clockwise gyre extending throughout most of the ocean. A full cycle of this gyre is estimated to take approximately 3-5 years (Macdonald et al., 2000). Some of the northward flowing water, that contains PFOA from the point source in Japan enters the Bering Sea and flows across the Bering Strait into the Arctic Ocean. This transport, which accounts for 2-8\% of the total PFOA transport into the Arctic Ocean, is a net inflow driven by a mean sea level slope down to the north. The slope is primarily a consequence of a steric level difference between the North Pacific and the Arctic Ocean of approx. $0.5 \mathrm{~m}$ (Overland, 1987). The temporal pattern of PFOA transport differs for the individual straits. While inflow of PFOA via the Norwegian Sea increased over time, inflow via the Bering Strait has been decreasing from 19912004. Changes in the water budget across these lines were analysed in terms of the barotropic stream function. Water mass transport in the Davis and Bering straits was found to be decreasing, while water transport in the Norwegian Sea and Denmark Strait was increasing over the simulated period of time. This evolution of the volume transport differs from what was found in reality. The predicted state of the nearArctic ocean on the example of the Bering Strait showed an increase of the volume transport between 1998 and 2001, and a subsequent decrease until 2004, while the opposite, a decrease 1998-2001 followed by an increase until 2004, was found in reality (Woodgate, 2006). Hence, mentioned years always refer to historical years in terms of the emissions, but not the physical state of the real world. In our simulation, the emissions are increasing abruptly by more than $60 \%$ in 1994. Similarly, the PFOA import to the Artic is increasing from approximately 15 to $25 \mathrm{t}$ in 1997 . The time lag of 3 years between emission strength and contaminant import is shorter than the transfer time of 5-10 years estimated from passive tracer studies (Dahlgaard, 1995). In these studies Atlantic water from European coasts was traced along the Norwegian Coast to the Barents Sea. The line in the Norwegian Sea is located much further south, and therefore passed much earlier. The transfer time to the Barents Sea predicted by the model is approximately 5 years, and, hence, in line with previous estimates. The fact that PFOA transport via the Bering Strait is decreasing over time indicates that the increase of PFOA emissions does not necessarily translate into increasing amounts reaching the Arctic. Also, the temporal pattern of the outflow from the Arctic Ocean through the Canadian Archipelago/Davis Strait reflects neither the inflow via the Norwegian Sea or Davis Strait, nor the emission strength variations. In fact, the mean streamfunction shows that water transport is decreasing over time in both straits (Fig. 9). Outflow via the Davis Strait is increasing from 1991-2001, but decreasing from 2001-2004. In contrast, the outflow of the contaminant through the Denmark Strait is increasing over time throughout the decade studied, apparently as a consequence of the increasing water inflow (Fig. 9). Moreover, as a consequence of the diverging inflow patterns and the Arctic ocean circulation a very inhomogeneous spatial distribution of PFOA evolves over the 54 years (AOT + spin-up) of model simulation. By 2004, the maximum PFOA burden is located in the Laptev Sea, east of Severnaya Semlja (not shown here). 
a.

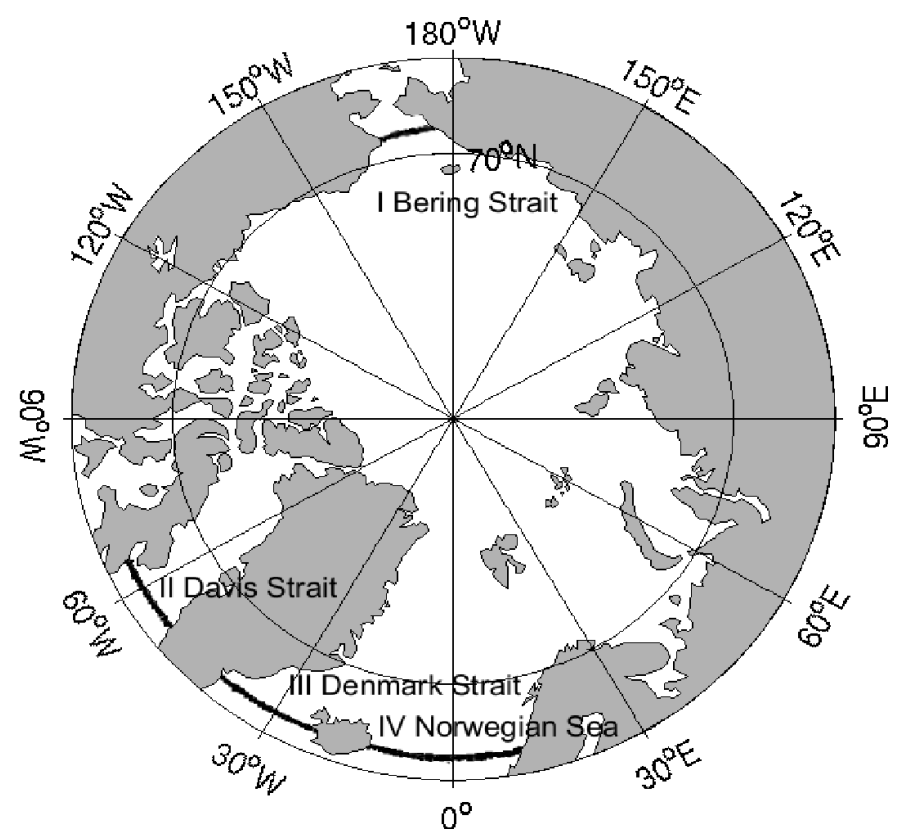

b.
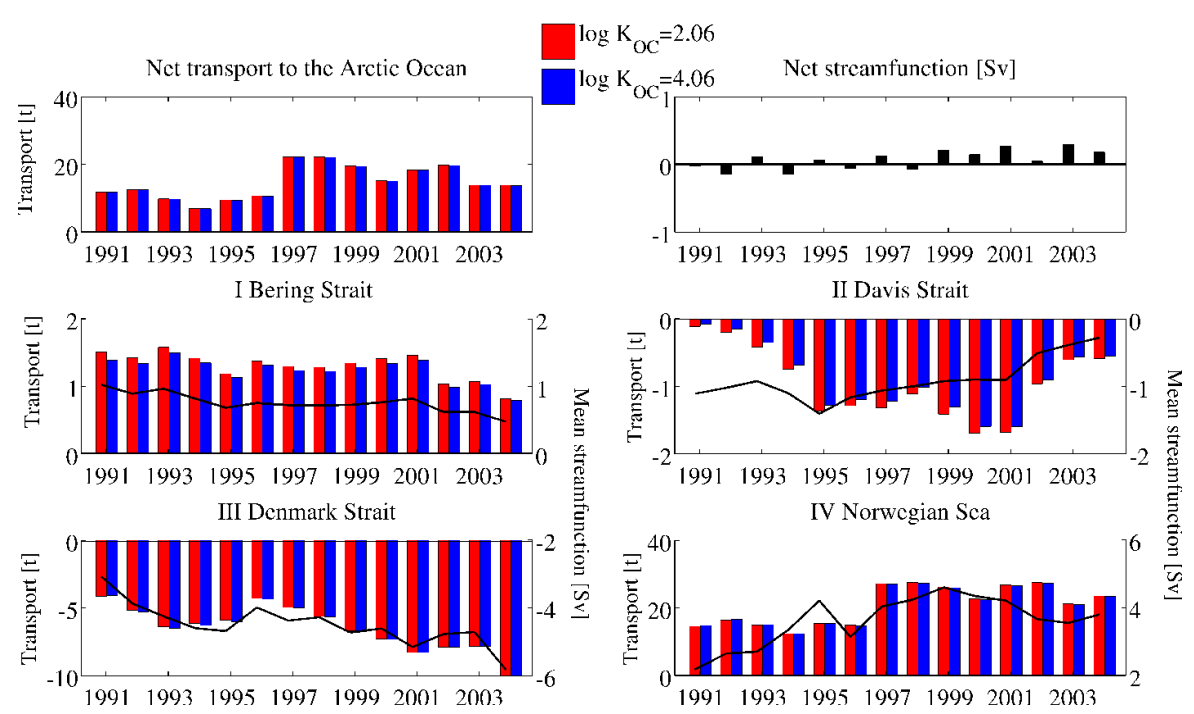

Fig. 9. Time series of annual transports $\left[\mathrm{ta}^{-1}\right]$ of PFOA (two substance scenarios) into the Arctic ocean and annual mean stream functions [Sv], (a) locations of 4 cross sections surrounding the Arctic ocean, (b) total and individual contributions through these cross sections. Bars denote PFOA transports, solid lines volume transports of water [Sv].

In our decoupled model approach we underestimated poleward oceanic transports, as depositions to the ocean did not include secondarily formed PFOA. In particular, input via the Norwegian Sea will be more significant in reality, due to maxima of PFOA deposition in mid latitudes of the North Atlantic Ocean. The low conversion efficiency of FTOH into
PFOA ( $\approx 0.05 \%$, see above), however, causes also the deposition to the global ocean to be dominated by primary emissions. In consequence, the underestimate of oceanic PFOA transport into the Arctic (AOT experiment) is very small, $<1.3 \%$. Decadal-scale variability and long-term changes in water transport are caused by salinity changes (fresh water 
discharge, ice formation), and variability of the atmospheric circulation $(\mathrm{AO} / \mathrm{NAO})$ and are subject to climate change. The predicted state of the Northern Hemisphere atmosphere on the example of the AO index is $0.04( \pm 1.05)$, while it was $0.14( \pm 1.03)$ in reality during the years 1993-1998 (Thompson and Wallace, 2000). A figure of the monthly mean AO indices for 1993-1998 can be found in the Supplement. Allocation of interannual variability to historic years would be possible by observation-forced ocean model simulation. In general, the fluctuations in oceanic transport of PFOA reflect the complex interaction of interannually varying 3-D oceanic currents and emission strengths. The mean state of the ocean in the coupled model ECHAM5/MPIOM was evaluated by Jungclaus et al. (2006). It was shown, that the main features of the mean water mass transports to the Arctic Ocean (in terms of the zonal streamfunction and meridional overturning circulation) are covered by the model. The total water budget of the Arctic Ocean is closed in the long-term mean (Fig. 9), and contributions to the total contaminant flux through the individual straits matches the mean relative contribution of water transport in the straits to total water transport.

\section{Summary and conclusions}

Large-scale transport of primary emitted and secondarily formed PFOA was modeled for the first time with a global coupled atmosphere-ocean circulation model. Poleward transports of PFOA are episodic with a seasonal preference for winter (Arctic haze) in the atmosphere and subject to a strong inter-annual variability in the ocean. The latter pathway dominated the overall transport to the Arctic in recent decades. This finding is certainly robust against model limitations, in particular a highly simplified emission scenario which neglects $\approx 40 \%$ of the global (primary) emission strength and neglects other precursors than 8:2 FTOH for secondary PFOA, as the relative significance of atmospheric and oceanic transports deviate by more than an order of magnitude in the $1990 \mathrm{~s}\left(14.8 \pm 5.0\right.$ vs. $\left.\approx 1 \mathrm{ta}^{-1}\right)$ and a modelgenerated climate. But, the effect of uncertainties of physicochemical properties $\left(\mathrm{pK}_{\mathrm{a}}\right)$ on PFOA multicompartmental fate and transport is a tendency to overestimate the atmospheric burden and lifetime and, hence, atmospheric transport, which will partly compensate for neglection of precursors. Besides precursors emission strengths there is also a contribution of the atmospheric dynamics on the inter-annual variability of PFOA formation in atmospheric chemistry and atmospheric long-range transport. This should be addressed by a longer (decades) simulation forced by observed or model-generated climate. The emission scenario used was concentrating many sources into only four point sources. As part of the riverine sources to the ocean had been located more northerly than in reality (redirecting the contribution of sources in the Mississippi basin into the St. Lawrence basin), historic imports into the Arctic via Atlantic currents may in reality have been lagging somewhat behind the model prediction. The chemodynamics simulated is linked to the historically unique emissions of the pollutant and its precursors during the simulated period. Therefore, the conclusions are historically explicit and cannot be taken as representative for previous or future periods. To this end model experiments using adapted emission scenarios and, eventually, state of climate would be needed.

This study demonstrated that, indeed, knowledge of the ocean circulation and its variations is crucial to understand PFOA's large-scale distribution and fate. This applies also for other contaminants, because a large fraction of the total environmental burden of many persistent organic pollutants is stored in seawater, much more than in the atmosphere (Guglielmo et al., 2009). Accumulation and distribution of anthropogenic organic substances in the ocean on long (decadal) time scales is largely unknown. Especially in a warming climate, if, as predicted by simulations performed under the IPCC scenarios, the thermohaline circulation weakens in the North Atlantic, the contaminant inflow into the Arctic will also be affected, as it is largely determined by the ocean circulation rather than the emission pattern. Furthermore, it was found, that the ocean circulation may lead to a strongly inhomogeneous distribution of PFOA, even in remote regions such as the Arctic. This is related to different residence times of chemical trace substances for different ocean regions and at different depths. While the ocean initially acts as a sink for all anthropogenic substances, airsea exchange of organics more volatile and less polar than PFOA may reverse after decades in those sea regions where accumulation is fastest, i.e. the ocean acts as a secondary source (Bidleman et al., 1995; Stemmler and Lammel, 2009) and even more so a warming ocean.

State of knowledge and model parameterisations are deficient with regard to amphiphilic substances behaviour in the environment, which accumulate on surfaces and interfaces. Dissociation, gas-particle partitioning and partitioning to colloids and sedimenting particles in the hydrosphere could be severely underestimated by bulk approaches (Tolls and Sijm, 2000; Goss and Arp, 2009; Arp and Goss, 2009). Improved parameterisations should be tested in highly process-resolved box models. Exploring these uncertainties by means of substance scenarios with regard to sorption to aerosols (Armitage et al., 2009) and organic phases (this work) suggest little impact on large-scale distribution and fate.

\section{Supplementary material related to this article is available online at: http://www.atmos-chem-phys.net/10/9965/2010/ acp-10-9965-2010-supplement.zip.}


Acknowledgements. Irene Stemmler was supported by the International Max Planck Research School for Maritime Affairs, Hamburg, and the Max Buchner Research Foundation. The authors are grateful to Francesca Guglielmo for valuable discussions, and Gabriela Sousa Santos (both MPI-M) for providing radical distributions. This project was supported by the European Commission (7-th FWP R\&D 226534, ArcRisk).

The service charges for this open access publication have been covered by the Max Planck Society.

Edited by: J. G. Murphy

\section{References}

Aakrog, A., Boelskifte, S., Duniec, S., Hallstadius, S., Holm, E., and Smith, J.: Technetium 99 and Caeium-134 as long-distance tracers in Arctic waters, Estuar. Coast. Shelf Sci., 24, 637-647, 1987.

AMAP: AMAP assessment 2002 - Persistent organic pollutants in the Arctic, Arctic Monitoring and Assessment Programme, Oslo, Norway, 2004.

Armitage, J., Cousins, I. T., Buck, R. C., Prevedouros, K., Russell, M. H., MacLeod, M., and Korzeniowski, S. H.: Modeling globalscale fate and transport of perfluorooctanoate emitted from direct sources, Environ. Sci. Technol., 40, 6969-6975, 2006.

Armitage, J., MacLeod, M., and Cousins, I.: Modeling the global fate of perfluorooctanoic acid (PFOA) and perfluorooctanoate (PFO) emitted from direct sources using a multispecies mass balance model, Enivorn. Sci. Technol., 43, 1134-1140, 2009.

Arp, H. P. H. and Goss, K. U.: Gas/particle partitioning behaviour of perfluorocarboxylic acids with terrestrial aerosols, Environ. Sci. Technol., 43, 8542-8547, 2009.

Arp, H. P. H., Niederer, C., and Goss, K. U.: Predicting the partitioning behaviour of various higly fluorinated compounds, Environ. Sci. Technol., 40, 7298-7304, 2006.

Barber, J., Berger, U., Chaemfa, C., Huber, S., Jahnke, A., Temme, C., and Jones, K.: Analysis of per- and polyfluorinated alkyl substances in air samples from Northwest Europe, J. Environ. Monit., 9, 530-541, 2007.

Barrie, L., Gregor, D., Hargrave, B., Lake, R., Muir, D., Shearer, R., Tracey, B., and Bidleman, T.: Arctic contaminants: sources, occurrence and pathways, Sci. Total. Environ., 122, 1-74, 1992.

Barton, C., Kaiser, M., and Russell, M.: Partitioning and removal of perfluorooctanoate during rain events: the importance of physical-chemical properties, J. Environ. Monit., 9, 839-846, 2007.

Bidleman, T., Jantunen, L., Falconer, B., Barrie, L., and Fellin, P.: Decline of hexachlorocyclohexane in the Arctic atmosphere and reversal of air-sea gas exchange, Geophys. Res. Lett., 22, 219222, 1995.

Boulanger, B., Peck, A. M., Schnoor, J., and Hornbuckle, K.: Mass Budget of Perfluorooctane Surfactants in Lake Ontario, Environ. Sci. Technol., 39, 74-79, 2005.

Brace, N.: Long chain alkanoic and alenoic acids with perfluoroalkyl terminal segments, J. Org. Chem., 40, 4491-4493, 1962.

Burns, D. C., Ellis, D. A., Li, H. X., McMurdo, C. J., and Webster, E.: Experimental pKa determination for perfluorooctanoic acid
(PFOA) and the potential impact of $\mathrm{pKa}$ concentration dependence on laboratory-measured partitioning phenomena and environmental modeling, Environ. Sci. Technol., 42, 9283-9288, 2008.

Dahlgaard, H.: Transfer of European coastal pollution to the Arctic, Mar. Poll. Bull., 31, 3-7, 1995.

Eckhardt, S., Stohl, A., Beirle, S., Spichtinger, N., James, P., Forster, C., Junker, C., Wagner, T., Platt, U., and Jennings, S. G.: The North Atlantic Oscillation controls air pollution transport to the Arctic, Atmos. Chem. Phys., 3, 1769-1778, doi:10.5194/acp3-1769-2003, 2003.

Eckhardt, S., Breivik, K., Manø, S., and Stohl, A.: Record high peaks in PCB concentrations in the Arctic atmosphere due to long-range transport of biomass burning emissions, Atmos. Chem. Phys., 7, 4527-4536, doi:10.5194/acp-7-4527-2007, 2007.

Emmons, L. K., Walters, S., Hess, P. G., Lamarque, J. F., Pfister, G., Fillmore, D., Granier, C., Guenther, A., Kinnison, D., Laepple, T., Orlando, J., Tie, X., Tyndall, G., Wiedinmyer, C., Baughcum, S. L., and Kloster, S.: Description and evaluation of the model for ozone and related chemical tracers, version 4 (MOZART-4), Geosci. Model Dev. 3, 43-67, 2010.

Goss, K. U.: The pKa values of perfluorooctanoic acid and other highly fluorinated carboxylic acids, Environ. Sci. Technol., 42, 456-458, 2008.

Goss, K.-U. and Arp, H.: Comment on "Experimental $\mathrm{pK}_{\mathrm{a}}$ determination for Perfluorooctanoic Acid (PFOA) and the potential impact of $\mathrm{pK}_{\mathrm{a}}$ concentration dependence on laboratory-measured partitioning phenomena and environmental modeling", Environ. Sci. Technol., 43(13), 5150-5151, 2009.

Guglielmo, F., Lammel, G., and Maier-Reimer, E.: Global environmental cycling of DDT and $\gamma-\mathrm{HCH}$ in the 1980 s - a study using a coupled atmosphere and ocean general circulation model, Chemosphere, 76, 1509-1517, 2009.

Hagemann, S., Arpe, K., and Roeckner, E.: Evaluation of the hydrological cycle in the ECHAM5 model, J. Climate, 19, 3810-3827, 2006.

Halsall, C., Bailey, R., Stern, G., Barrie, L., Fellin, P., Muir, D., Rosenberg, B., Rovinsky, F., Kononove, E., and Pastukhov, B.: Multi-year observations of organohalogen pesticides in the Arctic atmosphere, Environ. Pollut., 102, 51-62, 1998.

Higgins, C. P. and Luthy, R. G.: Sorption of perfluorinated surfactants on sediments, Enivorn. Sci. Technol., 40, 7251-7256, 2006.

Hung, H., Blanchard, P., Halsall, C., Bidleman, T., Stern, G., Fellin, P., Muir, D., Barrie, L., Jantunen, L., Helm, P., Ma, J., and Konoplev, A.: Temporal and spatial variabilities of atmospheric polychlorinated biphenyls (PCBs), organochlorine (OC) pesticides and polycyclic aromatic hydrocarbons (PAHs) in the Canadian Arctic: Results from a decade of monitoring, Sci. Total. Environ., 342, 119-144, 2005.

Hurley, M. D., Andersen, M. P. S., Wallington, T. J., Ellis, D. A., Martin, J. W., and Mabury, S. A.: Atmospheric chemistry of perfluorinated carboxylic acids: Reaction with $\mathrm{OH}$ radicals and atmospheric lifetimes, J. Phys. Chem. A, 108, 615-620, 2004.

IIASA GGI Scenario Database: International Institute for Applied System Analysis, Laxenburg, Austria, online available at: http: //www.iiasa.ac.at/Research/GGI/DB/, 2007.

Iversen, T.: Chemical Exchange Between the Atmosphere and Polar Snow, 143, Atmospheric transport pathways for the Arctic, 
71-92, NATO ASI Ser., 1996.

Jungclaus, J., Botzet, M., Haak, H., Keenlyside, N., Luo, J.-J., Latif, M., Marotzke, J., Mikolajewicz, U., and Roeckner, E.: Ocean circulation and tropical variability in the coupled model ECHAM5/MPI-OM, J. Climate, 19, 3952-3972, 2006.

Kaiser, M. A. , Larsen, B. S., Kao, Ch-P. C., and Buck, R.: Vapor pressures of perfluorooctanoic, -nonanoic, -decanoic, undecanoic, and dodecanoic acids, J. Chem. Eng. Data, 50, 1841-1843, 2005.

Kim, S. and Kannan, K.: Perfluorinated acids in air, rain, snow, surface runoff, and lakes: Relative importance of pathways to contamination of urban lakes, Environ. Sci. Technol., 41, 83288334, 2007.

Lammel, G., Feichter, J., and Leip, A.: Long-range transport and global distribution of semivolatile organic compounds: A case study on two modern agrochemicals, MPI Report No. 324, Max Planck Institute for Meteorology, Hamburg, Germany, 2001

Macdonald, R., Barrie, L., Bidleman, T. F., Diamond, M., Gregor, D., Semkin, R.G.and Strachan, W., Li, Y., Wania, F., Alaee, M., Alexeeva, L., Bailey, S., Bewers, J., Gobeil, C., Halsall, C., Harner, T., Hoff, J., Jantunen, L., Lockhart, W., Mackay, D., Muir, D., Pudykiewicz, J., Reimer, K., Smith, J., Stern, G., Schroeder, W., Wagemann, R., and Yunker, M.: Contaminants in the Canadian Arctic: 5 years of progress in understanding sources, occurrence and pathways, Sci. Total. Environ., 254, $93-$ 234, 2000

Maier-Reimer, E.: Geochemical cycles in an ocean circulation model: Preindustrial tracer distributions, Global Biogeochem. Сy., 7, 645-677, 1993.

Maier-Reimer, E., Kriest, I., Segschneider, J., and Wetzel, P.: The HAMburg Ocean Carbon Cycle Model HAMOCC5.1 - Technical Description Release 1.1-, MPI Reports on Earth System Science, 14, 1-57, 2005.

Marsland, S., Haak, H., Jungclaus, J., Latif, M., and Röske, F.: The Max-Planck-Instistute global ocean-sea ice model with orthogonal curvelinear coordinates, Ocean Modell., 5, 91-127, 2003.

Martin, J., Smithwick, M., Braune, B., Hoekstra, P. F., Muir, D., and Mabury, S.: Identification of long-chain perfluorinated acids in biota from the Canadian Arctic, Environ. Sci. Technol., 38, 373-380, 2004.

Martin, J. W., Ellis, D. A., Mabury, S. A., Hurley, M. D., and Wallington, T. J.: Atmospheric chemistry of perfluoroalkanesulfonamides: Kinetic and product studies of the $\mathrm{OH}$ radical and $\mathrm{Cl}$ atom initiated oxidation of $\mathrm{N}$-ethyl perfluorobutanesulfonamide, Environ. Sci. Technol., 40, 864-872, 2006.

Overland, J. E., and Roach, A. T.: Northward flow in the Bering and Chukchi Seas, J. Geophys. Res., 92, 7097-7105, 1987.

Piekarz, A., Primbs, T., Field, J., Barofsky, D., and Simonich, S.: Semivolatile fluorinated organic compounds in Asian and Western U.S. air masses, Environ. Sci. Technol., 41, 8248-8255, 2007.

Prevedouros, K., Cousins, I. T., Buck, R. C., and Korzeniowski, S. H.: Sources, fate and transport of perfluorocarboxylates, Environ. Sci. Technol., 40, 32-44, 2006.

Roeckner, E., Bäuml, G., Bonaventura, L., Brokopf, R., Esch, M., Giorgetta, M., Hagemann, S., Kirchner, I., Kornblüh, L., Manzini, E., Rhodin, A., Schlese, U., Schulzweida, U., and Tompkins, A.: The atmospheric general circulation model ECHAM5 part 1: Model description, MPI Report No. 349, MPI for Meteorology, Hamburg, 2003.

Roesch, A. and Roeckner, E.: Assessment of snow: cover and surface albedo in the ECHAM5 general circulation model, J. Climate, 19, 3828-3843, 2006.

Sakurai, T., Serizawa, S., Isobe, T., Kobayashi, J., Kodama, K., Kume, G., Lee, H.J., Maki, H., Imaizumi, Y., Suzuki, N., Horiguchi, T., Morita, M., and Shiraishi, H.: Spatial, phase and temporal distributions of perfluorooctanesulfonate (PFOS) and perfluorooctanoic acid (PFOA) in Tokyo Bay, Japan, Environ Sci. Technol., 44, 4110-4115, 2010.

Schenker, U., Scheringer, M., MacLeod, M., Martin, J. W., Cousins, I. T., and Hungerbühler, K.: Contribution of volatile precursor substances to the flux of perfluorooctanoate to the Arctic, Environ. Sci. Technol., 42, 3710-3716, 2008.

Sellevåg, S. R., Kelly, T., Sidebottom, H., and Nielsen, C. J.: A study of the IR and UV-Vis absorption cross-sections, photolysis and $\mathrm{OH}$-initiated oxidation of $\mathrm{CF}_{3} \mathrm{CHO}$ and $\mathrm{CF}_{3} \mathrm{CH}_{2} \mathrm{CHO}$, Phys. Chem. Chem. Phys., 6, 1243-1252, 2004.

Semeena, V. S., Feichter, J., and Lammel, G.: Impact of the regional climate and substance properties on the fate and atmospheric long-range transport of persistent organic pollutants examples of DDT and $\gamma$-HCH, Atmos. Chem. Phys., 6, 12311248, 2006, http://www.atmos-chem-phys.net/6/1231/2006/.

Semeena, V. S. and Lammel, G.: Effects of various scenarios of entry of DDT and $\gamma-\mathrm{HCH}$ on the global environmental fate as predicted by a multicompartment chemistry-transport model, Fresen Environ. Bull., 12, 925-939, 2003.

Shindell, D. T., Chin, M., Dentener, F., Doherty, R. M., Faluvegi, G., Fiore, A. M., Hess, P., Koch, D. M., MacKenzie, I. A., Sanderson, M. G., Schultz, M. G., Schulz, M., Stevenson, D. S., Teich, H., Textor, C., Wild, O., Bergmann, D. J., Bey, I., Bian, H., Cuvelier, C., Duncan, B. N., Folberth, G., Horowitz, L. W., Jonson, J., Kaminski, J. W., Marmer, E., Park, R., Pringle, K. J., Schroeder, S., Szopa, S., Takemura, T., Zeng, G., Keating, T. J., and Zuber, A.: A multi-model assessment of pollution transport to the Arctic, Atmos. Chem. Phys., 8, 5353-5372, doi:10.5194/acp-8-5353-2008, 2008.

Shoeib, M., Harner, T., and Vlahos, P.: Perfluorinated chemicals in the Arctic atmosphere, Enivorn. Sci. Technol., 40, 7577-7583, 2006.

Six, K. D., and Maier-Reimer, E.: Effects of plankton dynamics on seasonal carbon fluxes in an ocean general circulation model, Global Biogeochem. Cy., 10, 559-583, 1996.

Smit, A. A. A. M. F. R., van den Berg, F., and Leistra, M.: Estimation method for the volatilization of pesticides from fallow soil, Environmental Planning Bureau Series 2, DLO Winand Staring Centre, Wageningen (The Netherlands), 1-104, 1997.

Stemmler, I. and Lammel, G.: Cycling of DDT in the global environment 1950-2002: World ocean returns the pollutant, Geophys. Res. Lett., 36, L24602, doi:10.1029/2009GL041340, 2009.

Stier, P., Feichter, J., Kinne, S., Kloster, S., Vignati, E., Wilson, J., Ganzeveld, L., Tegen, I., Werner, M., Balkanski, Y., Schulz, M., Boucher, O., Minikin, A., and Petzold, A.: The aerosolclimate model ECHAM5-HAM, Atmos. Chem. Phys., 5, 11251156, doi:10.5194/acp-5-1125-2005, 2005.

Stock, N., Furdui, V., Muir, D. C. G., and Mabury, S.: Perfluoroalkyl contaminants in the Canadian Arctic: evidence of atmospheric transport and local contamination, Environ. Sci. Tech- 
nol., 41, 3529-3536, 2007.

Sulbaek Andersen, M. P., Toft, A., Nielsen, O. J., Hurley, M. D., Wallington, T. J., Chishima, H., Tonokura, K., Mabury, S. A., Martin, J. W., and Ellis, D. A.: Atmospheric chemistry of perfluorinated aldehyde hydrates $\left(\mathrm{n}-\mathrm{C}_{x} \mathrm{~F}_{2 x}+1 \mathrm{CH}(\mathrm{OH})_{2}, \mathrm{x}=1,3,4\right)$ : Hydration, dehydration, and kinetics and mechanism of $\mathrm{Cl}$ atom and $\mathrm{OH}$ radical initiated oxidation, J. Phys. Chem. A, 110, 98549860, 2006.

Theobald, N., Gerwinski, W., and Jahnke, A.: Occurence of perfluorinated organic acids in surface sea water of the East Atlantic Ocean between $53^{\circ}$ North and $30^{\circ}$ South, Poster presentation at the SETAC Europe Annual Meeting, Porto, Portugal, 20-24 May, 2007.

Thompson, D. W. J. and Wallace, J. M.: Annular Modes in the Extratropical Circulation. Part I: Month-to-Month Variability, J Climate, 13(5), 1018-1036, available at: http://www.atmos. colostate.edu/ao/Data/ao_index.html, 2000.

Tolls, J. and Sijm, D.: Handbook of property estimation methods for chemicals, chap. Estimating the properties of surface-active chemicals, CRC Press, Boca Raton, USA, 419-445, 2000.

Tomasič,V., Chittofrati, A., and Kallay, N.: Thermodynamic properties of aqueous solutions of perfluorinated ionic surfactants, Colloids and Surfaces, Physicochemical and Engeneering Aspects, 40, 7577-7583, 1995.

US EPA : Draft Risk Assessment of the Potential Human Health Effects Associated With Exposure to Perfluorooctanoic Acid and Its Salts, EPA Science Advisory Board (SAB), 2005.

Wallington, T. J., Hurley, M. D., Xia, J., Wuebbles, D. J., Sillman, S., Ito, A., Penner, J. E., Ellis, D. A., Martin, J., Mabury, S. A., Nielsen, O. J., and Sulbaek Andersen, M. P.: Formation of $\mathrm{C} 7 \mathrm{~F} 15 \mathrm{COOH}$ (PFOA) and other perfluorocarboxylic acids during the atmospheric oxidation of 8:2 Fluorotelomer Alcohol, Environ. Sci. Technol., 40, 924-930, 2006.
Wang, R., Tao, S., Wang, B., Yang, Y., Lang, C., Zhang, Y., Hu, J., Ma, J., and Hung, H.: Sources and pathways of polycyclic aromatic hydrocarbons transported to Alert, the Canadian high Arctic, Environ. Sci. Technol., 44, 1017-1022, 2010.

Wania, F.: A global mass balance analysis of the source of perfluorocarboxylic acids in the Arctic ocean, Environ. Sci. Technol., 41, 4529-4535, 2007.

Wesely, M.: Parameterization of surface resistances to gaseous dry deposition in regional-scale numerical models, Atmos. Environ., 23, 1293-1304, 1989.

Woodgate, R. A., Aagaard, K., and Weingartner, T. J.: Interannual changes in the Bering Strait fluxes of volume, heat and freshwater between 1991 and 2004, Geophys. Res. Lett., 33, L15609, doi:10.1029/2006GL026931, 2006.

Yamashita, N., Taniyasu, S., Petrick, G., Wei, S., Gamo, T., Lam, P. K. S., and Kannan, K.: Perfluorinated acids as novel chemical tracers of global circulation of ocean waters, Chemosphere, 70, 1247-1255, 2008.

Yarwood, G., Emball-Cook, S., Keinath, M., Waterland, R., Korzeniowski, S., Buck, R., Russell, M., and Washburn, S.: Highresolution atmospheric modeling of fluorotelomer alcohols and perfluorocarboxylic acids in the North American troposphere, Enivorn. Sci. Technol., 41, 8248-8255, 2007.

Young, C., Furdui, V.I., Franklin, J., Koerner, R., Muir, D., and Mabury, S.: Perfluorinated acids in Arctic snow: new evidence for atmospheric formation, Environ. Sci. Technol., 41, 34553461, 2007. 